\title{
A COISA JULGADA NO PROCESSO CIVIL CANÔNICO: ENTRE A SEGURANÇA E A CERTEZA*
}

\author{
RES JUDICATA IN CANON LAW: BETWEEN SAFETY AND CERTAINTY
}

\section{Lia Carolina Batista *}

\begin{abstract}
Resumo:
O presente estudo trata da evolução histórica do instituto da coisa julgada no âmbito do processo canônico. O estudo histórico tem o objetivo de investigar a configuração do instituto ao longo da história e demonstrar que o seu desenvolvimento deu-se entre duas exigências opostas: a segurança e a certeza. Essas duas exigências têm especial relevância também no direito canônico vigente, particularmente no tocante à exigência da dupla conformidade e seu significado nas causas matrimoniais.
\end{abstract}

Palavras-chave: Coisa julgada. Direito canônico. Segurança. Certeza.

\begin{abstract}
:
The present study is about the evolution of res judicata under canon law. The historical study aims to investigate the configuration of the institute throughout history and demonstrate that its development took place between two opposing requirements: safety and certainty. These two requirements are particularly important in current canon law, especially regarding the requirement of two sentences in the same direction and its meaning in matrimonial cases.
\end{abstract}

Keywords: Res judicata. Canon law. Safety. Certainty.

1. Introdução

A coisa julgada é instituto que revela a intensa influência que o direito canônico exerceu, na história, sobre o direito laico. ${ }^{1}$ Entretanto, o interesse no estudo

\begin{abstract}
A Autora dedica este artigo ao Prof. José Rogério Cruz e Tucci e ao Dr. José Rubens de Moraes, que fizeram despertar nela o interesse pela pesquisa e ofereceram-lhe subsídios para isso. A eles, com grande admiração e gratidão por tudo o que representam em sua formação. Esclareça-se, aqui, por oportuno, que o termo "certeza" é utilizado ao longo deste trabalho para significar a busca de um resultado o mais próximo possível da verdade. Embora o termo "certeza" seja equívoco e preste-se até mesmo a indicar a palavra à qual aqui se opõe, qual seja segurança, optou-se por sua utilização em razão de os cânones 1608 do Código Canônico vigente e 1869 do Código Canônico de 1917 falarem de certeza moral como requisito para a pronúncia da sentença.

** Mestranda em Direito Processual Civil na Universidade de São Paulo. <lia.batista@gmail.com>.

"Non sarebbe possibile infatti comprendere il formarsi e l'evolversi della teoria del giudicato nel diritto comune, prescindendo dall'apporto dell'elemento canonistico e dall'esigenza etico-religiosa di questo diritto per l'affermazione della verità e della giustizia" (MUSSELLI, Luciano. Il concetto di giudicato nelle fonti storiche del diritto canonico (dalle origini al XVII secolo). Padova: CEDAM, 1972.II concetto di giudicato nelle fonti storiche del diritto canonico (dalle origini al XVII secolo). Padova: CEDAM, 1972, p. 1). Preferiu-se, aqui, utilizar a expressão 'direito laico' no lugar de 'direito comum', pois esta última não se distingue completamente, no sentido histórico, do direito canônico (ver, nesse sentido, TUCCl, José Rogério Cruz e; AZEVEDO, Luiz Carlos de. Lições de processo civil canônico (história e direito vigente).
\end{abstract}


da coisa julgada no Direito Canônico não se resume à História do Direito, pois ainda hoje o regime particularizado da coisa julgada nesse específico ramo do direito desperta a atenção dos estudiosos.

Como afirma Eduardo Talamini, "talvez nenhum instituto no processo da igreja revista-se como esse de tantas peculiaridades, em contraste com os modelos processuais laicos. Tais particularidades só são justificadas à luz dos valores essenciais do direito canônico" 2

Nesse sentido, para que se compreenda a razão que justifica as supracitadas particularidades, será necessário estudar o contexto do surgimento do Direito Canônico bem como os fundamentos que hoje - e desde o passado - o sustentam.

À guisa de introdução, é necessário afirmar que as normas processuais de direito canônico, como ressaltam José Rogério Cruz e Tucci e Luiz Carlos de Azevedo, apresentam dupla instrumentalidade. Isso porque além de toda norma processual ser instrumental, no sentido de estar voltada à realização do direito material, as normas processuais canônicas estão voltadas também - como, de resto, todas as outras - ao objetivo da salvação das almas (salus animarum). Essa característica fica muito evidente no tratamento conferido à coisa julgada, embora isso não tenha ocorrido desde o início da formação do direito canônico.

No direito laico, sempre que se procede ao estudo da coisa julgada, partese da premissa de que constitui uma opção política, para justificar, em certos casos, a prevalência da segurança sobre a certeza.

Como o direito canônico tem fundamento diverso do direito laico, a opção axiológica que fundamenta a coisa julgada - e que constitui o fundamento último de todo o direito canônico - está estritamente ligada à salvação das almas, o que faz com que em alguns casos a segurança ceda perante a certeza (e não necessariamente perante a justiça), ${ }^{3}$

São Paulo: Revista dos Tribunais, 2001, p. 43). Seria até gramaticalmente correta a utilização da expressão direito comum em contraposição à expressão direito canônico, pois este último é, sem dúvidas, um direito especializado, não-comum, mas é sempre preferivel manter-se fiel à utilização tradicional das expressões, para que seu significado não se esvazie.

2 Cf. TALAMINI, Eduardo. Eficácia e autoridade da sentença canônica. Revista de Processo, São Paulo, v. 107, p. 24, jul./set. 2002. Carlos Henrique Soares afirma que "todo o processo civil canônico é pautado sob a perspectiva da doutrina católica e questões extraprocessuais advindas da religiosidade servem de fundamento para permitir abalar as disposições sobre a coisa julgada. Percebe-se que a intenção do direito material e processual canônico é, sem sombra de dúvida, a busca pela justiça e a verdade divina e, no momento em que questões de ordem processual, especificamente a coisa julgada, se contrapõem a esse ideal, devem ser modificadas" (SOARES, Carlos Henrique. Coisa julgada constitucional: teoria tridimensional da coisa julgada: justiça, segurança jurídica e verdade. Coimbra: Almedina, 2009. p. 40).

3 Afirma Carlos Henrique Soares que "além do aspecto técnico-processual, deve-se levar em consideração também o fundamento teleológico. Assim, havendo conflito entre segurança jurídica e a justiça, tende-se para o lado da justiça como elemento necessário para atingir a verdade divina" (SOARES, Carlos Henrique. Coisa julgada constitucional, cit., p. 40). Entretanto, embora vejamos de forma cristalina a oposição entre segurança e certeza, essa mesma oposição não se dá, necessariamente, entre segurança e justiça. Como bem 
o que se verifica no fato de algumas decisões não transitarem em julgado. Por esse motivo, há quem aponte estarem no direito canônico os fundamentos para a flexibilização da coisa julgada. $^{4}$

Com efeito, é precisa a afirmação de Eduardo Talamini no sentido de que "os provimentos que afrontam os valores mais caros a uma dada ordem jurídica não merecem dessa ordem respaldo para se tornar absolutamente imunes à revisão. Eis, em síntese, a explicação jurídica do princípio canônico da 'não-passagem em julgado' E é precisamente essa a idéia que está na base dos discursos da relativização da coisa julgada e do repúdio à coisa julgada inconstitucional - temas que estão na ordem do dia do processo civil brasileiro" 5

Não fosse por todos os outros motivos que serão expostos neste trabalho, justificar-se-ia o estudo da coisa julgada no direito canônico tão só pelo fato de ser atribuída aos canonistas a evolução no estudo do instituto, na medida em que se deixou de identificar, como faziam os romanos, a coisa julgada com a própria sentença.

Procurar-se-á, neste estudo, portanto, estudar, em primeiro lugar, a necessidade de se ter um direito da Igreja para depois tratar brevemente da formação do direito canônico na história e de seu fundamento, a salvação das almas. Assim estarão reunidas as premissas para se proceder ao estudo específico da coisa julgada ao longo da história do direito canônico e no direito canônico vigente.

Por fim, é necessário desde já alertar que o estudo ficará restrito ao fenômeno da formação da coisa julgada, sem qualquer preocupação em tratar especificamente de

leciona Tércio Sampaio Ferraz Jr., "falar da justiça como uma aspiração constitucional não pode significar outra coisa que sua realização enquanto realização dos direitos fundamentais" (FERRAZ JR., Tércio Sampaio. Segurança jurídica, coisa julgada e justiça. Revista do Instituto de Hermenêutica Jurídica, Porto Alegre, v. 1, n. 3, 2005, p. 270). Também merece menção Andrea Bettetini: "Specificamente, quell'insieme di atti formali successivi e tra loro logicamente concatenati che danno vita a un processo destinato a concludersi con una decisioni, nel diritto della Chiesa, come del resto in ogni ordenamento, ha per fine la ricerca e l'accertamento della verità fattuale e di ciò che è giusto, con particolare riguardo all'acclaramento di un'eventuale lesione di interessi per ricomporla in modo certo e giuridicamente efficace. Ciò attuando mediante il riconoscimento e l'attribuzione a ognuno di quanto gli spetta" (Cf. BETTETINI, Andrea. Verità, giustizia, certezza: sulla cosa giudicata nel diritto della chiesa. Padova: CEDAM, 2002. p. 4).

4 Apesar de parecer não haver correspondência entre o fato de uma decisão não transitar em julgado (como ocorre no direito canônico, por disposição expressa do Código) e a possibilidade de se flexibilizar uma coisa julgada já existente, o fato é que, como se verá, as decisões canônicas que não transitam em julgado adquirem imutabilidade muito semelhante - se não idêntica - à das demais decisões que transitam em julgado.

5 TALAMINI, Eduardo. Eficácia e autoridade da sentença canônica. cit., p. 60. No mesmo sentido, Carlos Henrique Soares afirma que "também se revestem de fundamental importância para o estudo da coisa julgada as idéias defendidas pelo direito canônico, principalmente quando se pretende tratar a possibilidade de rescisão de uma sentença que, de alguma forma, viola as leis canônicas, as quais, por se fundarem em bases religiosas, pressupõem a vontade de Deus. É no direito canônico que encontramos o embrião da tese sobre a 'flexibilização da coisa julgada"' (SOARES, Carlos Henrique. Coisa julgada constitucional. cit., p. 23). 
seus limites, quer subjetivos, quer objetivos, embora estes últimos recebam menção indireta no estudo da dualidade entre conformidade equivalente e conformidade formal como exigência para formação da coisa julgada.

2. É realmente necessário um "Direito da Igreja”?

Eis os questionamentos de Martin Segú Girona: "Há necessidade de um corpo jurídico na igreja? Este corpo jurídico poderia ser considerado como sendo de instituição divina? Será que um corpo de leis é necessário para a caminhada libertadora e a própria instituição do Reino? O corpo Jurídico foi por vontade de Cristo ou é simplesmente um mimetismo estrutural querendo a Igreja ter um Código para ser respeitada como Estado?" 6

Nas palavras do mesmo autor é possível afirmar que "não há antinomia alguma entre a Igreja da caridade e o corpo de Direito. São estes dois elementos os constitutivos da Igreja de Cristo, pelo fato da (sic) integrarem de modo inseparável, no entanto deve-se ter sempre presente que o elemento jurídico-social deve estar sempre a serviço da natureza espiritual e sobrenatural da Igreja e jamais o contrário a não ser que se queira subverter a ordem e descaracterizar a própria Igreja" ${ }^{7}$

O Direito, como é costumeiramente repetido, encontra seu fundamento e sua legitimidade nos valores existentes na sociedade em que é vigente. Ora, a Igreja não deixa de ser uma sociedade, a qual apresenta particularidades que justificam a existência de um "direito da Igreja". Assim, "concebido o direito como pilar necessário à manutenção e ao bem-estar de todos os grupos sociais, enfoque diverso não pode ser atribuído ao direito canônico" 8

Com efeito, "o direito canônico sempre se enquadrou diante de perspectiva que não se coaduna com a do direito laico. Num primeiro plano, com a prática do direito, volta-se a instituição da Igreja à proteção jurídica dos fiéis, possuindo as normas conteúdo espiritual e sobrenatural" 9

Algumas das causas disciplinadas pelo Código de Direito Canônico jamais seriam resolvidas pelo direito laico (por exemplo, a validade do sacramento do sacerdócio). É fato que a grande maioria das causas julgadas pelos tribunais eclesiásticos diz respeito ao matrimônio. São causas de anulação e separação que são vistas também todos os dias

6 Cf. GIRONA, Martin Segú. O Código de Direito Canônico é necessário na Igreja de Cristo? Revista de Cultura Teológica, São Paulo, v. 15, n. 58, jan./mar. 2007. p. 108.

7 Id. Ibid., p. 111.

8 PINTO, Junior Alexandre Moreira. Conteúdos e efeitos das decisões judiciais. São Paulo: Atlas, 2008. p. 19.

9 Id. Ibid., p. 19. 
nos fóruns comuns, mas mesmo essas causas são julgadas sob uma perspectiva totalmente diferente.

Para se ter uma comprovação disso, basta ter em mente que um casamento realizado unicamente sob a égide das leis civis é tido pela Igreja como mero concubinato. Não é necessário ir muito longe, então, para concluir que uma anulação de casamento feita por um juiz laico não surtiria qualquer tipo de efeito sobre o sacramento do matrimônio celebrado perante a Igreja.

Ademais, será que para o próprio cristão é suficiente que a anulação de seu matrimônio se dê por um juiz laico? Os valores da Igreja nem sempre são coincidentes com os valores da sociedade comum, o que torna necessário um ordenamento jurídico para a Igreja, não obstante a Igreja e o Estado tenham modos de atuação - no que diz respeito ao aspecto jurisdicional - muito semelhantes. ${ }^{10}$

O fato de o "direito da Igreja" ser de submissão voluntária - pois ao passo em que não é possível desvincular-se do império estatal, é possível desvincularse da Igreja - não o descaracteriza, pois não deixa a Igreja de, por isso, constituir uma verdadeira sociedade. E o direito é, nas palavras de Rafael Llano Cifuentes, veículo de ordem, renovação e liberdade. ${ }^{11}$

Transcrevendo passagem de Paulo VI, o supracitado canonista afirma que "assim quis o Senhor a sua Igreja: "uma verdadeira sociedade perfeita e soberana, com leis próprias, com autoridades próprias, com meios e fins próprios. É esta uma verdade fundamental da doutrina católica, que tem sólidas e claras raízes no Novo Testamento e uma realidade evidente na história da Igreja", 12

Para compreender a necessidade de um "direito da Igreja" é preciso compreender o fundamento da Igreja, que "no podría ser entendido rectamente, ni estudiado con fruto, prescindiendo del contexto de la fe" 13

A necessidade de tal direito específico é muito bem revelada em passagem da lavra de Edson Luiz Sampel: "Infelizmente, mesmo na comunidade Eclesial, onde deveriam viger o amor fraterno e a caridade, com imensa solicitude pelo próximo, sucedem contendas as mais diversas, que necessitam de uma resposta célere e enérgica, por parte da

10 Nesse sentido, afirma Rafael Llano Cifuentes que "diferenciando-se o Direito Canônico e o secular fundamentalmente pelas suas finalidades diversas, encontram-se, porém, no campo técnico e metodológico, comum a ambos os direitos" (LLANO CIFUENTES, Rafael. Curso de direito canônico: a Igreja e o Estado à luz do Vaticano II. São Paulo: Saraiva, 1971. p. 12). Vale ressaltar, entretanto, a exemplo de Zenon Grocholewski, que "mientras las legislaciones estatales toman em consideración a la persona humana en su dimensión terrena, es decir, principalmente desde su concepción hasta su muerte, el Derecho Canônico considera la persona en su dimensión eterna" (GROCHOLEWSKI, Zenon. La especificidad del derecho canonico. Anuario Argentino de Derecho Canonico, Santa Maria de los Buenos Aires, v. 12, 2005. p. 220).

1 LLANO CIFUENTES, Rafael. Curso de direito canônico. cit., p. 6.

12 Id. Ibid., p. 5, citando a Alocução de 26-5-1966.

13 GROCHOLEWSKJ, Zenon. La especificidad del derecho canonico. cit., p. 217. 
autoridade eclesiástica, a fim de que volte a reinar a paz, e o comportamento dos batizados sirva de testemunho para o mundo inteiro" 14

De acordo, mais uma vez, com Rafael Llano Cifuentes, "mostra-se a Igreja com duas dimensões bem definidas: é por um lado uma comunidade espiritual, mística, e, por outro, uma sociedade organizada" ${ }^{15}$ Tal idéia pode ser complementada com a afirmação de Zenon Grocholewski no sentido de que "así como la Iglesia es una sociedad única en su gênero, así ocurre con su Derecho" 16

O Direito Canônico tem, ainda, uma finalidade específica, a qual será detalhada no próximo item: a salvação das almas (salus animarum).

Quando se fala em "direito da Igreja", fala-se na necessidade de um direito material e, ainda, de um direito processual. Este último faz-se necessário ainda que no âmbito do direito canônico seja preferível a resolução extrajudicial dos conflitos.

Necessário verificar, por fim, quais são as causas que se encontram ao abrigo do ordenamento canônico.

De acordo com o cânone 1401 podem ser conhecidas pela Igreja as causas relativas às coisas espirituais e as com elas conexas e as relativas à violação das leis eclesiásticas e aos atos caracterizados como pecado, no que se refere à determinação da culpa e à imposição de penas eclesiásticas. Embora haja afirmação expressa no mencionado cânone de que tais causas são conhecidas com exclusividade pela Igreja, não é possível estender essa exclusividade plenamente às causas conexas, que, em princípio, são indeterminadas.

Embora as causas de competência da Igreja estejam relacionadas às coisas espirituais (dentre as quais os sacramentos), ao pecado e à violação das leis eclesiásticas, tem-se que, para ser parte no direito canônico, após o advento do Código de 1983, não é necessário ser batizado (cânone 1476). ${ }^{17}$

Ao final deste tópico, é possível, então, adotar um conceito de direito canônico. De acordo com Vincenzo Del Giudice, “si denomina ‘diritto canonico' il sistema delle norme giuridiche, stabilite o fatte valere dalla competente autorità della Chiesa

14 Cf. SAMPEL, Edson Luiz. Direito processual canônico. Revista de Cultura Teológica, São Paulo, v. 11, n. 43, p. 133, abr./jun. 2003.

is Cf. LLANO CIFUENTES, Rafael. Curso de direito canônico. cit., p. 2.

16 Cf. GROCHOLEWSKI, Zenon. La especificidad del derecho canónico. cit., p. 232.

17 Como esclarecem José Rogério Cruz e Tucci e Luiz Carlos de Azevedo, "no âmbito da revogada legislação, o não-católico (batizado ou não) somente poderia gozar da condição de parte em juízo se obtivesse expressa autorização do Santo Ofício. Durante a vigência do Código de 1917, a comissão de interpretação dos decretos do Concílio Vaticano II, em resposta datada de 8 de janeiro de 1973, devidamente aprovada pelo Papa Paulo VI, atribuiu capacidade processual aos não-católicos apenas nas causas matrimoniais" (TUCCl. José Rogério Cruz e; AZEVEDO, Luiz Carlos de. Lições de processo civil canônico... cit., p. 109-110). 
cattolica, secondo le quali è ordinata e opera essa Chiesa, e dalle quali è regolata l'attività dei fedeli, in relazione ai fini che della Chiesa son propri" 18

A autonomia do direito canônico é plena em relação à fonte emanadora de normas; entretanto, em relação às causas conhecidas pela Igreja, pode haver conflito de competência com o Estado, o que será abordado no item 5.6 infra.

\section{O fundamento do Direito Canônico: a salvação das almas (salus animarum)}

Parece possível afirmar que assim como não existiu a distinção entre sentença e coisa julgada desde o início do direito canônico (v. item 4, infra), o princípio da salvação das almas também não vigorou com tanta força desde o princípio. Pode-se dizer que tal princípio foi sendo evidenciado na medida em que o direito canônico passou a ser organizado da perspectiva interna.

É de se ressalvar que a princípio, entretanto, o direito canônico voltou suas atenções para a perspectiva externa, da autonomia e do poder. Com efeito, o direito canônico nasce de vicissitudes políticas para só depois olhar para dentro de si e construir seu fundamento religioso.

Esclareça-se, aqui, que não se confunde nesse ponto a Igreja com o "direito da Igreja" Aquela sempre teve como preocupação a salvação das almas, princípio este que, entretanto, nem sempre esteve presente de forma marcante no "direito da Igreja"

Destaca-se, nesse sentido, a lição de José Reinaldo de Lima Lopes no sentido de que "o desenvolvimento do direito canônico não pode ser analisado sem conexão com as disputas pelo poder que se travam a partir do século XI entre Igreja e Império, mais tarde também entre Igreja e Estados nacionais, e com o desenvolvimento material da vida européia a seguir o fim das grandes invasões por volta do ano 1000" 19

Conseqüência disso, para estabelecer relação com o objeto do presente estudo, arrisca-se a afirmar, é o fato de o Decreto de Graciano, datado de 1140, até admitir exceções à imutabilidade da sentença, mas, a princípio, vinculadas ao simples aprimoramento da justiça da decisão (rationabilitas). O fundamento da salus animarum ainda não se fazia presente como fundamento da possibilidade de se modificar as sentenças.

Nesse mesmo sentido, Eduardo Talamini afirma, com relação à exclusão da coisa julgada nas ações de estado, que "durante a evolução histórica do princípio em exame, a definição dos valores que o justificariam foi por muito tempo imprecisa. Inicialmente, se o vinculou ao simples aprimoramento da justiça da decisão (a rationabilitas a que aludiu

18 Cf. DEL GIUDICE, Vincenzo. Sommario di diritto canonico. Milano: Giuffrè, 1946. p. 3.

19 LOPES, José Reinaldo de Lima. O direito na história: lições introdutórias. 3 ed. São Paulo: Atlas, 2008 . p. 68. 
Graciano). Depois passaram-se a invocar razões espirituais, mas quase sempre de modo amplo ou vago", 20

Leciona ainda o supramencionado autor que "foi depois da 'estabilização" do direito canônico com o Decretum que se veio a esboçar o princípio da permanente possibilidade de determinadas causas serem revistas. Coube aos glosadores do Decretum, às decretais de Papas posteriores e às obras de outros doutrinadores essa tarefa. Foi então que se formulou o conceito de transitus in rem iudicatam, 'trânsito em julgado' 'passagem em julgado" É que, até esse momento, res iudicata era noção que se identificava com a da própria sentença ou, quando menos, com o efeito essencial de qualquer sentença. No instante em que se começaram a conceber sentenças que não eram imutáveis, já não era mais possível a identificação entre as duas categorias. Daí a distinção entre a sentença, considerada em si mesma, e a 'passagem em julgado' consistente na condição de irrevogabilidade, que não precisa estar presente em todas as sentenças" ${ }^{21}$ Essa evolução será estudada detalhadamente no tópico referente à história da coisa julgada no direito canônico.

É possível verificar um movimento de espiritualização do direito canônico, como se verá mais adiante, durante a contra-reforma. ${ }^{22}$

Hoje, entretanto, é indiscutível a influência da salus animarum, que permeia todo o ordenamento jurídico canônico. A referência à salus animarum como lei suprema da Igreja é expressa no Código de Direito Canônico de 1983, como pode ser verificado no cânone 1752: "Nas causas de transferência, apliquem-se as prescrições do cân. 1747 , respeitando-se a eqüidade canônica e tendo diante dos olhos a salvação das almas que, na Igreja, deve ser sempre a lei suprema" (sem destaque no original).

Há debate intenso, entretanto, como noticia Piero Pellegrino, no tocante à sobreposição ou não da salus animarum à lei. ${ }^{23}$ Parece razoável entender que a lei já foi elaborada à luz da influência da salus animarum e, além disso, como complementação, deve ser interpretada sempre de forma que a favoreça, pois se trata de fundamento religioso e imutável.

Ou seja, "la salus animarum non costituisce e rappresenta soltanto un fine a cui il diritto deve tendere, ma costituisce un qualcosa di immanente alla Chiesa stessa. La salvezza delle anime non sarebbe allora un elemento metagiuridico o stragiuridico, così come è stato finora considerato da tutti i canonisti, e soprattutto dai più autorevoli, ma tale elemento va riportato nell'interno dell'ordinamento canonico, poiché tale diritto non

TALAMINI, Eduardo. Eficácia e autoridade da sentença canônica. cit., p. 43.

Id. Ibid., p. 28-29.

MUSSELLI, Luciano. Il concetto di giudicato nelle fonti storiche del diritto canonico... cit., p. 104.

23 Cf. PELLEGRINO, Piero. La salus animarum. Ius Canonicum, Navarra, v. 64, 11. 87, p. 141-151, enero/jun. 2004. 
è 'una struttura sociologica della Chiesa' bensì un fenomeno sociale con un'autonomia epistemologica e logica propria" ${ }^{24}$

Piero Pellegrino afirma ainda que "tutti gli istituti e le norme dell'ordinamento canonico vengono a incontrare nella loro legitimità di esistenza e possibilità di attuazione il limite fondamentale dell'ordine pubblico della Chiesa, per cui non debbono essere in contrasto con i principi direttivi, con i compiti essenziali e con le finalità supreme dell'ordinamento canonico stesso. È inutile ricordare che, se per gli Stati, il concetto di ordine pubblico è un concetto essenzialmente politico e contingente, al contrario, per la Chiesa è un concetto essenzialmente dogmatico, religioso e immutabile e che si il fine degli Stati è un fine politico e modificabile, quello della Chiesa è un fine religioso, fisso e immutabile" 25

Como se vê, a salus animarum pode ser equiparada, em certa medida, à noção de ordem pública do ordenamento processual civil estatal.

No que diz respeito ao objeto do presente estudo, tem-se que a salus animarum faz-se bastante presente no instituto da coisa julgada, uma vez que, no direito canônico, a segurança, muitas vezes, cede perante a certeza para que assim seja possível livrar-se do pecado e alcançar a salvação das almas. Manuel Jesus Arroba Conde chega a afirmar que no direito canônico o instituto da coisa julgada foi recebido moderadamente. ${ }^{26}$

São comuns, assim, na doutrina, afirmações no sentido de que "en el sistema procesal canonico la certeza del derecho cede siempre ante el principio del favor veritatis cuando se demuestra que la verdad objetiva contradice manifestamente la verdad procesal" 27

4. A coisa julgada na história do Direito Canônico - principais aspectos ${ }^{28}$

A coisa julgada, como revela o próprio título do presente trabalho, é um instituto que se situa entre duas exigências. ${ }^{29}$ Nesse sentido, Andrea Bettetini afirma que

24 PELLEGRINO, Piero. La salus animarum. Ius Canonicum, Navarra, v. 64, n. 87, p. 141-151, enero/jun. 2004. p. 148-149.

25 Id. Ibid.

26 CONDE, Manuel Jesus Arroba. Direito processual canônico. 5. ed. Roma: Institutum Iuridicum Claretianum, 2006. p. 671 .

27 ZUBILLAGA, José L. López. La conformidad de decisiones en el código de 1983. Revista Española de derecho canónico, Salamanca, v. 59, n. 153, jul./dic. 2002. p. 670.

28 Esclareça-se aqui que duas obras foram primordiais no estudo da história da coisa julgada no direito canônico, quais sejam, a de Luciano Musselli e a de Andrea Bettetini, ambas devidamente citadas nas referências ao final do texto. Optou-se, entretanto, por seguir a sistematização ofertada por Luciano Musselli por ter parecido mais clara e de mais fácil compreensão.

29 Precisas são, nesse sentido, as palavras de Juan José García FAİLDE: “A veces en la legislación entra en conflicto la exigencia de la búsqueda incesante de la verdad objetiva con la necesidad de conformarse (contentarse) con um juicio (sentencia) que afirma con certeza haber alcanzado esa verdad objetiva; 
"se la natura umana ha bisogno di verità, ha altrettanto bisogno di certezza e stabilità nelle relazioni giuridiche, per non vivere in una continua inquietudine su sé stessa che non le permetterebbe di adempiere alla propria vocazione ecclesiale e divina" 30

Referido conflito de valores é intrínseco à coisa julgada e revela-se no ordenamento canônico vigente, mas também no estudo da história do instituto.

Adianta-se que a reconstrução histórica que será desenvolvida não é absolutamente linear por dois motivos: a escassez bibliográfica e a desnecessidade de se tratar de cada passo do desenvolvimento histórico da coisa julgada, sendo certo que serão destacados apenas os aspectos mais importantes necessários à compreensão do instituto.

\subsection{Algumas palavras sobre o Direito Romano}

Não é possível falar do instituto da coisa julgada no direito canônico - e principalmente de sua influência sobre o direito laico - sem tratar de sua história.

É necessário, como quase na totalidade dos casos, partir do direito romano, pois "i canonisti ed i civilisti del medioevo, come del resto accadde per la quase totalità degli istituti giuridici, mutuarono dal diritto romano l'idea e la terminologia della $<<r e s$ judicata $>>$, interpretandola e modificandola onde adattarla alla nuova situazione religiosa e sociale", 31

Não se pode, entretanto, abordar o direito romano, que se desenvolveu durante séculos, como um todo homogêneo, como se transformações não tivessem ocorrido ao longo do tempo.

Ao longo da evolução do direito romano, o momento de consumação da ação passa da litis contestatio, no período formulário, para a decisão final no período da cognitio extra ordinem..$^{32}$ É nesse último período do direito romano que tem cabimento a afirmação segundo a qual "le espressioni $<<$ sententia $>>$ e $<<$ res judicata $>>$ non rappresentavano altro che due punti di vista da cui definire il medesimo fenomeno" 33

necesidad ésta reclamada a su vez por la necesidad de que se ponga fin a la sucesión interminable de pleitos sobre un asunto que crearían incertidumbres e inseguridades en las relaciones jurídicas y por ello desorden en la convivencia social; entonces la legislación suele arbitrar diversos procedimientos de los que unos se inclinan por esta necesidad con detrimento de aquella exigencia de seguir buscando la verdad ontológica (como sucede con la figura jurídica de la 'cosa juzgada') y otras optan por esa búsqueda incesante de la verdad objetiva con detrimento de aquella necesidad (como ocurre com la figura jurídica de la 'revisión de causa')" (FAİlDE, Juan José García. Derecho procesal canónico: estudo sistemático-analítico comparado. 3. ed. Salamanca: Publicaciones Universidad Pontificia, 1995. p. 21).

30 BETTETINI, Andrea Bettetini. Verità, giustizia, certezza. cit., p. 14.

31 MUSSELLI, Luciano. Il concetto di giudicato nelle fonti storiche del diritto canonico, cit., p. 3.

32 Ver, nesse sentido, MUSSELLI, Luciano. Il concetto di giudicato nelle fonti storiche del diritto canonico. cit., especialmente p. 3-7 e TALAMINI, Eduardo. Coisa julgada e sua revisão. São Paulo: Revista dos Tribunais, 2005. p. 197-214.

33 MUSSELL1, Luciano. Il concetto di giudicato nelle fonti storiche del diritto canonico, cit., p. 4. 


\subsection{Generalidades sobre a coisa julgada no Direito Canônico}

A idéia de coisa julgada como concebida hoje, como se vê, era estranha ao direito romano. E era estranha também ao direito canônico, em sua origem. ${ }^{34}$ Nesse sentido, Eduardo Talamini, ao tratar da obra de Graciano, afirma que "o decreto acolhia a noção romana de coisa julgada (c. 2, C. 6, q. 29)" ${ }^{35} \mathrm{Em}$ complemento a isso, afirma ainda que - e aqui pede-se vênia para transcrever mais uma vez a passagem - "na época de Graciano, a idéia que se tinha de coisa julgada era ainda aquela da simples 'definição judicial' da questão, herdada do Direito Romano. A noção de 'passagem em julgado' (transitus in rem iudicatam), no sentido de uma qualidade de irrevogabilidade da sentença - e não a sentença em si mesma -, é uma criação canônica, mas posterior a Graciano" 36

Desse modo, é possível acolher na íntegra a lição de Luciano Musselli segundo a qual "il concetto del passagio in giudicato della sentenza per via del trascorrere un certo numero di giorni, senza che siano state proposte impugnazioni, si fomerà molto più tardi, come vedremo, proprio ad opera dei canonisti dell'età di mezzo, nella loro lunga e appassionata ricerca per una sistemazione logico-dottrinale del problema del giudicato" 37

O jurista italiano afirma que a noção de trânsito em julgado começou a se formar entre a exigência ética de se rejeitar a sentença injusta sob pena de se viver em pecado (periculum animae) e a exigência de política judiciária que demandava certeza na definição das controvérsias (sobretudo nas questões patrimoniais), havendo, no passado, grande variação na disciplina do tema, que ia desde a proibição do recurso ou de sua limitação numérica à ampla abertura para a possibilidade de revogação da sentença injusta e lesiva. ${ }^{38}$

Mas é de se observar, nesse sentido, que "la novità portata dal diritto canonico al proposito non è di carattere prevalentemente tecnico (in quanto dal punto di vista tecnico e terminologico a parte l'elaborazione della teoria del passaggio in giudicato, ben poco i canonisti innovarono in questo campo) bensì funzionale, riguardante cioè l'uso che di questo complesso di strumenti si fece, sotto la spinta di motivi di natura etico-

34 Vale transcrever a lição segundo a qual "durante il periodo, che va dalla fine dell'impero romano alla raccolta di Graziano, la legislazione ecclesiastica e le prime opere di dottrina (sopratutto in forma di raccolta di diposizioni conciliari), non si occuparono, almeno a quanto mi consta, direttamente e particolarmente del problema concettuale del giudicato, concentrandosi piuttosto l'attenzione del mondo giuridico sui fenomeni più lati e comprensivi del <<judicium $>>$ " (MUSSELLI, Luciano. Il concetto di giudicato nelle fonti storiche del diritto canonico, cit., p. 9).

35 TALAMINI, Eduardo. Eficácia e autoridade da sentença canônica. cit., p. 27.

36 Id. Ibid., p. 28. Será explicitado, entretanto, que embora Graciano, como afirma Eduardo Talamini, tenha "adotado" a noção romana de coisa julgada, ele já previa a existência de diversas exceções à imutabilidade. Cf. MUSSELLI, Luciano. Il concetto di giudicato nelle fonti storiche del diritto canonico. cit., p. 5.

38 MUSSELLI, Luciano. Il concetto di giudicato nelle fonti storiche del diritto canonico (dalle origini al XVII ${ }^{\circ}$ secolo). Padova: CEDAM, 1972. p. 10-11. 
religiosa estranei alla mentalità romanistica e poi civilistica, quali la 'salus animarum' ed il 'periculum peccati', per citarne alcuni tra i più comuni" 39

Vale lembrar que a evolução histórica da coisa julgada esteve muito ligada ao problema da ficção ou da presunção de verdade e da discussão sobre o fato de a coisa julgada criar ou não uma verdade. ${ }^{40}$ Merece menção ainda o fato de que houve, ao longo da história, algumas discrepâncias teóricas que fugiram à sistematização abaixo desenvolvida; apenas para exemplificar, é possível citar a concepção contratual da sentença e da coisa julgada defendida por Bartolo. ${ }^{41}$

\subsection{O Decreto de Graciano}

No que toca à legislação canônica, o ponto de partida é quase sempre a obra de Graciano $(1140)^{42}$ e, como era de se esperar, uma vez que a proposta de sua obra era a concordância dos cânones, ele se encontra diante de duas concepções divergentes de julgado, a romana, baseada na irrevogabilidade, e a canônica, da necessária prevalência da verdade, e acaba deixando transparecer, segundo Luciano Musselli, uma certa preferência pela concepção romana, não sem revelar certa tortuosidade em seu pensamento, com a admissão de algumas exceções à irrevogabilidade..$^{43}$

Em passagem do Decreto em que Graciano admite a possibilidade de anulação, pelos sucessores, da sentença obtida pelos predecessores com base em presunções temerárias, propugna a distinção entre sentenças rationabiliter datae, essas imutáveis, e sentenças obtidas mediante fraude, as quais poderiam ser corrigidas, pois o juiz teria sido induzido em erro. Seriam verdadeiras sentenças apenas aquelas obtidas sem qualquer fraude das partes. ${ }^{44}$

Outra exceção - muito mais ampla que a primeira, acima exposta - seria aquela segundo a qual, nos dizeres de Luciano Musselli, "anche Graziano, a proposito della sentenza di scomunica, arriva a dire che la sentenza ingiusta non lega né $<<$ apud

39 Id. Ibid., p. 141.

40 Nesse sentido, cf. BETTETINI, Andrea. Verità, giustizia, certezza, cit., p. $42-58$.

4I BETTETINI, Andrea. Verità, giustizia, certezza. cit., p. 86 e ss. Essa concepção contratual do processo e de seus elementos, se não encontra guarida no processo civil estatal, muito menos no processo canônico.

${ }_{42}$ Afirma Aloísio SURGIK que "Fernando Della Rocca, em substancioso estudo sobre o processo em Graciano [Saggi, p. 203 e ss], conclui observando que o Decretum, indubitavelmente, constitui - com os elementos do processo que nele se encontram dispersos - o passo inicial para se formar, no campo dos canonistas que seguiram o impulso de Graciano, uma consciência e un trabalho sobre os quais passou a basearse a communis opinio, necessária à Igreja, de um ordenamento processual próprio" (SURGIK, Aloísio. Compêndio de direito processual canônico. Curitiba: Livro é Cultura, 1988. p. 19).

43 Cf. MUSSELLI, Luciano. Il concetto di giudicato nelle fonti storiche del diritto canonico (dalle origini al $\mathrm{XVII}^{\circ}$ secolo). Padova: CEDAM, 1972. p. 15.

44 Id. Ibid., p. 15-16. 
Deum >> né <<apud Ecclesiam>> (c. 64, C. XI, q. IX)" ${ }^{45}$ Graciano faz, ainda, uma distinção entre três principais tipos de injustiça segundo (i) surja da violação de normas procedimentais, (ii) diga respeito a deficiência de pressupostos e motivos da decisão ou (iii) venha a ser proferida pelo juiz influenciado psicologicamente a favor ou contra uma das partes, distinguindo também em relação a seus efeitos. ${ }^{46} \mathrm{~A}$ despeito desses três tipos de injustiça, em relação à imutabilidade da decisão, Graciano tende a configurar apenas dois gêneros de injustiça, a substancial e a aparente, irrelevante. ${ }^{47}$

Luciano Musselli conclui, após o estudo do Decreto de Graciano, que ele cai em certa contradição "dovuta senza dubbio alla disparità ed alle antinomie, contenute nei testi, da cui cerca di estrarre una 'ratio communis"', mas considera relevante que tenha exposto a mutabilidade da sentença do ponto de vista da justiça. ${ }^{48}$

Seriam ainda exceções à imutabilidade as sentenças decorrentes de dolo e aquelas pronunciadas ilicitamente (ou seja, contra a lei), sempre revogáveis, não obstante o transcurso do tempo. Realmente imutáveis eram apenas as sentenças efetivamente motivadas por razões jurídicas. ${ }^{49}$

Assim, Graciano, "nella sua opera di mediazione fra le due tendenze ricordate egli sansisce sì il valore vincolativo del giudicato, ma anche procede a tipizzare in via straordinaria i casi in cui la sentenza può essere egualmente impugnata dopo il termine d'appello" ${ }^{50}$

Como última observação ao tratamento da coisa julgada no Decreto de Graciano, nota-se que "Graziano, riprendendendo in ciò la tradizione romanistica del Codex Justiniani, partendo dalla generica proibizione della 'triplex appellatio' ci dia uno dei primi accenni alla nozione della doppia conforme, come fatto processualmente preclusivo e creatore di giudicato". 51

Para Andrea Bettetini, "nel diritto della Chiesa già Graziano iniziò a distinguere fra sentenza e cosa giudicata, subordinando la formazione di questa alla mancata proposizione dell'appello".52 Além disso, já em Graciano se falava de coisa julgada quando houvesse uma decisão de segundo grau confirmativa de uma decisão precedente. Assim, "non solo quindi una causa disponeva di due gradi di giurisdizione, ma in questi due gradi doveva esaurirsi nella sua completezza" ${ }^{53}$

\footnotetext{
45 MUSSELLI, Luciano. Il concetto di giudicato nelle fonti storiche del diritto canonico (dalle origini al XVII ${ }^{\circ}$ secolo). Padova: CEDAM, 1972. p. 16.

46 Id. Ibid., p. 16-17.

47 Id. Ibid., p. 18.

48 Id.; Ibid., p. 19.

49 Id. Ibid., p. 20.

so Id. Ibid., p. 21.

si Id. Ibid., p. 22.

52 BETTETINI, Andrea. Verità, giustizia, certezza... cit., p. 29.

53 Id. Ibid., p. 31.
} 


\subsection{Algumas summae}

Após Graciano, muitas outras importantes obras canônicas trataram da coisa julgada. Em relação ao tema analisado, em verdade, tais obras foram ainda mais significativas que o Decreto, pois foram aprimorando seu conceito, que era ainda muito pouco claro para Graciano.

Entre tais obras, destacam-se, como aponta Luciano Musselli, as summae ${ }^{54}$ de Rufino, Giovanni de Faenza, Bernardo Baldi e sobretudo Uguccione, sendo que nessas obras, pela primeira vez, há aplicação sistemática do critério da ratio peccati ${ }^{55}$ em matéria de coisa julgada, estando presente desde Rufino a idéia de que as causas espirituais não toleram a ficção de verdade. A idéia de trânsito em julgado, entretanto, aparecerá apenas na obra de Uguccione. ${ }^{56}$

\subsubsection{Rufino}

Vale ressaltar que Rufino já distingue entre causas comuns e espirituais, sendo que nessas últimas, com especial menção às causas matrimoniais, "si ammette la revocazione della sentenza, indipendentemente dal vizio che la inficia, così che qualunque causa di ingiustizia possa minarla" ${ }^{57}$ As sentenças nas causas comuns também seriam revogáveis, mas em alguns casos especificamente determinados, não genericamente como as sentenças nas causas espirituais (e criminais).

Rufino, assim como Bernardo, não faz distinção, em matéria de coisa julgada nas causas matrimoniais, entre sentenças pró e contra matrimônio. ${ }^{58}$

Por fim, Rufino retoma a teoria dos três tipos de injustiça de Graciano, desenvolvendo-a em termos gerais e não mais restrita a determinado tipo de sentença. ${ }^{59}$

54 Para esclarecer o que seriam essas summae, tem-se que conforme ensina Mons. Maurílio Cesar de LIMA, "além das aulas, os professores publicavam ou consentiam que se publicassem tratados de sua autoria, comentários em torno de diferente gênero ou finalidade: summaria, onde poucas palavras resumiam temas; glossae, que explicavam textos e se tornaram de grande importância para o estudo do Direito, a ponto de substituí-los no ensino, distintas como eram as interlineares (ou menores) ou as marginais (ou maiores)" (LIMA, Maurílio Cesar de. Introdução à história do direito canônico. 2 ed. São Paulo: Loyola, 2004. p. 112).

5s Essa aplicação sistemática não passa a existir abruptamente, tanto que Luciano Musselli em comentário à obra de Rufino afirma que ele considera a rationabilitas elemento essencial da sentença, sem o qual ela não pode ser vinculativa (MUSSELLI, Luciano. Il concetto de giudicato nelle fonti storiche del diritto canonico. cit., p. 25). Id. Ibid., p. 23-24.

57 Id. Ibid., p. 26.

58 Id. Ibid., p. 26. Vale mencionar que muito provavelmente essa concepção foi alterada ulteriormente, pois "fin quasi all'età moderna e comunque durante tutto il Medioevo, l'unica situazione di solito considerata di periculum peccati fu quella relativa al matrimonio 'male disiunctum', ammettendosi il passagio in giudicato delle sentenze date pro matrimonio" (Id. Ibid., p. 30).

s9 Id. Ibid., p. 26-27. 
Propõe ainda uma diversificação de efeitos: "mentre per lui la sentenza viziata dal punto di vista processuale ovvero solamente dallo stato psicologico del giudice ('ex ordine o 'ex animo') non doveva essere mutata, qualora esistessero i presupposti di fatto e di diritto per la condanna, una opposta soluzione era da adottarsi quando questi per contro mancassero, potendosi in questo tipo di "iniustitia ex causa "in utrolibet casu... sententia retractari" 60

\subsubsection{Bernardo de Pavia}

Nas palavras de Luciano Musselli, “anche Bernardo da Pavia, nella 'Summa de Matrimonio' come Rufino, ci dà uma delle prime affermazioni dottrinali della perpetua revocabilità delle sentenza in materia matrimoniale, sulla base dell'argomento del periculum animae che comincia ora a porsi come principale criterio valutativo in rapporto alla vincolatività del giudicato" 61

\subsubsection{Uguccione}

De acordo com Luciano Musselli, a summa de Uguccione foi a primeira na qual a teoria do trânsito em julgado e a afirmação de sua exceção com base no periculum animae aparece com maior profundidade. ${ }^{62}$

Uguccione, apresentando posição de vanguarda, defende que as causas penais, em nome da justiça, não transitam em julgado. Em relação às causas civis, distingue aquelas nas quais não há periculum animae, que conservam seu valor se a injustiça subsistente não configurar uma nulidade processual e aquelas nas quais há periculum animae, hipótese em que a sentença definitiva não pode aspirar nem a formar uma presunção de verdade nem a constituir coisa julgada dotada da força preclusiva característica. Assim, a idéia da salus animarum assume posição central na teoria de Uguccione sobre coisa julgada. ${ }^{63}$

É assim - distinguindo entre sentenças que transitam e sentenças que não transitam em julgado - que Uguccione sintetiza "il concetto dinamico e notorio della nuova concezione di 'res judicata' contrastante con la vecchia idea statica della 'res judicata' come 'res judicaliter deffinita' propria del diritto romano. E tale nuova teoria la cui origine, in diritto canonico, appare chiariamente strumentale ad una necessità di distinzione nell'ambito della sentenza, (tra quelle dotate della forza preclusiva del giudicato e quelle che ne erano prive), viene da Uguccione espressa in modo sintetico e chiaro: ...

\footnotetext{
60 MUSSELLI, Luciano. Il concetto di giudicato nelle fonti storiche del diritto canonico (dalle origini al XVII ${ }^{\circ}$ secolo). Padova: CEDAM, 1972., p. 27.

61 Id. Ibid., p. 30.

62 Id. Ibid., p. 31.

63 Id. Ibid., p. 32-33.
} 
sic ergo patet quod aliud est in aliis et aliud in causis criminalibus vel spiritualibus ubi vertitur periculum animae, in talibus enim causis ecclesiasticis sententia etiam post $X$ dies non facit jus nec transit in rem judicatam..." 64

Até aqui estudou-se detalhadamente como se deu a construção histórica do conceito de coisa julgada e de trânsito em julgado. E é possível afirmar que com Uguccione o direito canônico começou a se libertar das amarras da tradição do direito romano no que diz respeito à coisa julgada. ${ }^{65}$

Com efeito, com Uguccione surgiu no direito canônico o conceito de trânsito em julgado e alcançou-se concepção de coisa julgada praticamente idêntica à que se tem hoje, visto que o Código de Direito Canônico de 1983 afirma expressamente que não transitam em julgado as causas sobre o estado das pessoas, nas quais se evidencia a presença do periculum animae.

Vale mencionar a ressalva de Luciano Musselli no sentido de que "rimane da notare che pur essendosi in questo periodo enucleati e svolti i motivi essenziali inerenti alla teoria del 'transitus in judicatum' e della perpetua revocabilità delle sentenze rese in cause spirituali, motivi che, com'è noto, si conserveranno nel corso successivo del diritto canonico, non appare ancora in questa fase d'evoluzione della dottrina canonica, una compiuta ed organica teoria del giudicato, quale si avrà solo con i maggiori commenti alle Decretali" 66

De agora em diante, deixar-se-á de lado a construção histórica linear que vinha sendo desenvolvida até aqui para se destacar apenas os aspectos históricos mais importantes até se chegar à primeira codificação e, finalmente, ao Código vigente, para então passar-se ao estudo das peculiaridades da coisa julgada no atual direito canônico.

4.5. Outros desenvolvimentos históricos que antecederam as Decretais de Gregório IX

Para Riccardo Anglico, autor da Summa de Ordine judiciario, "la res judicata' non è solo la controversia definita mediante sentenza, ma è un particolare effeto confirmativo, un particolare via od auctoritas, che è propia di un solo tipo di sentenza: la

64 MUSSELLI, Luciano. Il concetto di giudicato nelle fonti storiche del diritto canonico (dalle origini al XVII ${ }^{\circ}$ secolo). Padova: CEDAM, 1972. p. 35.

65 Talvez seja possível afirmar que a completa libertação do direito romano não ocorreu ainda. Ao longo da história muitas vezes se voltou à concepção romana na conceituação de coisa julgada e ainda hoje alguns autores definem a coisa julgada - com algum equivoco - como, a exemplo de José L. López Zubillaga, "aquello que ha sido decidido por el juez para poner fin a um proceso" (ZUBILLAGA, José L. López. La doble decisión conforme en la doctrina procesal del código de 1917. Revista española de Derecho Canônico, Salamanca, v. 59, n. 152, enero/jun. 2002, p. 129).

${ }_{66}$ Cf. MUSSELLI, Luciano. Il concetto di giudicato nelle fonti storiche del diritto canonico... cit., p. 47. 
'sentenza deffinitiva" " 67 Afirmou ainda referido autor que não se reveste da autoridade de coisa julgada a sentença proferida contra o contumaz ausente por defeito na citação.

Como se vê, já se começa a falar na coisa julgada como efeito da sentença (concepção que hoje já está superada mas que à época representou um avanço).

Tancredi de Bologna, autor de Ordo Iudiciarius, na visão de Luciano Musselli, é outro autor que merece menção, pois é a primeira obra anterior às Decretais de Gregório IX que trata de modo exauriente e completo da matéria da sentença e de seus efeitos, acolhendo a teoria do trânsito em julgado, embora utilizasse terminologia antiga e de certa forma equivocada. Em referida obra, a concepção de passagem (trânsito) em julgado aparece pela primeira vez conceitualmente coordenada com os efeitos processuais e substanciais da sentença. ${ }^{68}$

Reaparece nesse momento histórico o tratamento unitário para as sentenças pró e contra matrimônio. ${ }^{69}$

\subsection{Decretais de Gregório IX}

Não há, nas Decretais de Gregório IX (1234), qualquer conceituação de coisa julgada, mas são encontradas "soluzioni immediate e concrete, sotto le quale sembra trasparire il permanere della concezione romanistica della 'res judicata' come preclusiva di una seconda pronuncia sullo stesso oggeto" " Entretanto, é a primeira vez que "la nuova teoria del 'transitus in rem judicatum' e delle eccezioni al principio del giudicato viene espressamente enunciata in una raccolta ufficiale dal legislatore canonico, anche se in modo incidentale" 71

Em resumo, "possiamo rilecare come nelle decretali ci siano, in genere, tutti gli elementi della moderna teoria del giudicato, che verrano poi enucleati ed elaborati dalla dottrina seguente" 72 Nota-se, ainda, "l'influsso dell'impostazione romanistica della 'res judicata' moderata dall'accoglimento della nuova e diversa teoria del passagio in giudicato delle sentenze" 73

\footnotetext{
67 MUSSELLI, Luciano. Il concetto di giudicato nelle fonti storiche del diritto canonico (dalle origini al XVII ${ }^{\circ}$ secolo). Padova: CEDAM, 1972. p. 38.

68 Id. Ibid., p. 38-40.

69 Id. Ibid., p. 41.

70 Id. Ibid., p. 49.

71 Id. Ibid., p. 50.

72 Id. Ibid., p. 56-57.

73 Id. Ibid., p. 57.
} 


\subsection{A doutrina posterior a Gregório IX}

É interessante destacar o posicionamento de Ostiene, autor da Summa Aurea, para quem existem três tipos de sentença, diferenciadas em razão da incidência da coisa julgada sobre elas: (i) sentenças proferidas em matéria espiritual que nunca passam em julgado, em razão do periculum animae; (ii) sentenças que passam imediatamente em julgado, que são as sentenças penais dadas em casos mais graves nos quais tenha havido confissão espontânea do réu, em razão da possibilidade de punição imediata e (iii) outras sentenças em geral, que passam em julgado com o decurso do tempo (dez dias) para interposição de apelação e não podem ser revogadas a não ser por meio da restitutio in integrum ou de outro remédio extraordinário. ${ }^{74}$

Merece menção também o nome de Inocêncio, em cuja obra são encontradas, de acordo com Luciano Musselli, as afirmações mais vivas da exigência de busca e valorização da verdade além e acima das exigências de certeza jurídica. ${ }^{75}$ Inocêncio "non solo sostiene che la regola del giudicato non tiene nelle cause d'interesse pubblico (quali quelle beneficiarie) od in cui possa ravvisarsi un periculum animae, ovvero laddove la sentenza appaia determinata nel suo tenore da prove false o dalla circonvenzione del giudice, ma arriva a dire che, in ogni caso, d'ingiustizia notoria, si deve rifare il giudizio, a prescindere dall'essere o meno trascorso il termine del passaggio in giudicato, 'quia veritas valet et invalescit' affermando al di là della forza e della suggestione del mito civilistico del giudicato, l'istanza irrinunciabile di giustizia del diritto della Chiesa" 76

Para Baldo, outro decretalista, coisa julgada e sentença são distintas enquanto a primeira sempre tem por base uma sentença e a sentença nem sempre forma coisa julgada. ${ }^{77}$ Afirma ainda o referido canonista que a nulidade de uma sentença subsiste apenas quando, além da injustiça, configurar também uma impossibilidade jurídica. Nos outros casos, a ausência de apelação demonstra a aquiescência tácita à sentença dada contra o direito do sucumbente (presunção de verdade). ${ }^{78}$

Em relação às causas matrimoniais, Baldo aceita a teoria segundo a qual não passam nunca em julgado, com exceção das sentenças pro matrimonio. ${ }^{79}$

Também se evidencia o pensamento de Giovanni d'Andrea, que aceita a solução proposta por Bartolo para o direito laico, o qual, para conciliar a concepção romanista e a canonista, afirmava que a expressão coisa julgada podia ser entendida de

\footnotetext{
${ }_{74}$ MUSSELLI, Luciano. Il concetto di giudicato nelle fonti storiche del diritto canonico (dalle origini al XVII ${ }^{\circ}$ secolo). Padova: CEDAM, 1972. p. 62-63.

75 Id. Ibid., p. 65.

76 Id. Ibid., p. 66.

77 Id. Ibid., p. 67.

78 Id. Ibid., p. 68.

79 Id. Ibid., p. 69.
} 
duas formas, ou como controvérsia judicialmente definida ou como estado de certeza que a própria decisão adquire com o transcurso do período de dez dias para apelação. ${ }^{80}$

Ainda falando de Giovanni d'Andrea, "un altro punto di grande interesse, per quanto riguarda l'apposto di questo autore alla materia del giudicato, è costituito dalla spiegazione del motivo per cui le sentenze in materia matrimoniale non soggiacciono alla regola generale del 'transitus in rem judicatum' spiegazione con la quale porta lla luce ed esprime, in termini chiari e sintetici, l'esigenza etica e teologica, che stava sotto, latente e sottintesa da secoli, alle espressioni 'periculum peccati', 'quando anima periclitaret' ed altre similari, usate al proposito dai canonisti di ogni tempo" 81

Por fim, o canonista cria a expressão res litigiosa para as sentenças que não transitam em julgado, "in riferimento alla lite che non si considera del tutto conchiusa" 82

Panormitani tenta, no século XV, construir uma nova teoria geral sobre o conceito de sentença e de coisa julgada, procurando criar uma nova ordem conceitual. Mencionado canonista "arriva a ritenere che la teoria civilistica del giudicato, neppure dopo lo sforzo conciliativo di Bartolo, cui s'ispira il D'Andrea, non possa reggersi e giustificarsi di fronti ai testi delle Decretali ove appare chiariamente sancita e canonizzata la teoria del "transitus in rem judicatam", 83

Além de rebater a teoria civilista, Panormitani, noticia Luciano MUSSELLI, faz uma bipartição conceitual entre coisa julgada, entendida no sentido civilista, e autoridade da coisa julgada, que seria a adição da qualidade de vinculatividade e de irrevogabilidade que a decisão adquire depois de dez dias. ${ }^{84}$

$\mathrm{Na}$ época, seu posicionamento fez com que Panormitani ficasse isolado na doutrina, mas é inegável seu mérito nos tempos modernos em razão do destaque dado ao conceito de autoridade da coisa julgada. ${ }^{85}$

Vale mencionar que Panormitani chega a dizer que sempre que uma sentença contenha um periculum animae, não há coisa julgada e que a simples injustiça conhecida pela parte vencedora seria suficiente para impedir a passagem em julgado. ${ }^{86}$ Nesse sentido, "l'eterno dilemma del diritto canonico, sulla attribuzione o meno della forzadel giudicato alla sentenza ingiusta nel merito viene qui risolto a favore della ratio spirituale di esso, che prevale sulle ragioni di politica giudiziaria, in forza ad un'argomentazione alla quale s'ispirerà, come vedremo, buona parte della dottrina e della giurisprudenza successiva. Ma

80 MUSSELLI, Luciano. Il concetto di giudicato nelle fonti storiche del diritto canonico (dalle origini al XVII ${ }^{\circ}$ secolo). Padova: CEDAM, 1972. p. 67 e 70.

Id. Ibid., p. 71.

Id. Ibid., p. 71.

Id. Ibid., p. 73.

Id. Ibid., p. 74.

Id. Ibid., p. 75.

Id. Ibid., p. 79. 
questa soluzione non deve essere vista soltanto come una teoria del giudicato elaborata da alcuni valenti canonisti quale Uguccione, Sinibaldo Fieschi e da ultimo Nicolò De Tudeschi ed affermatasi in forza alle loro argomentazioni, quanto come una risposta che il diritto canonico, nelle sue espressioni più sensibili alle istanze teologiche e religiose riesce a dare al problema che sorge dall'eterno contrapporsi dell'esigenza politico-giudiziaria di autorevolezza del deciso all'esigenza etico-religiosa della reale presenza della giustizia in ogni decisione" 87

Por fim, no que toca às causas matrimoniais, Panormitani reconhece que não passam em julgado, mas afirma gozarem tais sentenças de uma presunção de justiça que faz com que não possam ser impugnadas a não ser por motivos bem específicos, como, por exemplo, o erro e a fraude. ${ }^{88}$

Panormitani traz ainda algumas novidades relativas às sentenças penais, as quais não serão estudadas por não interessarem ao presente estudo.

A doutrina do cinquecento sofreu certa mescla entre o direito canônico e o direito laico, motivo pelo qual se vislumbra um período de decadência e de pouca força teórica, com maior importância dada à casuística, a qual alargou de modo pouco orgânico os casos de exceção ao trânsito em julgado, o que acaba, na opinião de Luciano MUSSELLI, provocando uma dissolução estrutural da coisa julgada. ${ }^{89}$

É possível vislumbar no cinquecento autores essencialmente canonistas, tais como Lancellotti e Decio, para os quais a teoria da coisa julgada manteve-se firme, e os cultores do processo comum, como Maranta e Saccia, que acabaram esvaziando e até mesmo negando, em sede teórica, a coisa julgada. ${ }^{90}$

Chega a causar perplexidade o elenco de exceções ao trânsito em julgado da sentença apresentado por Maranta, em obra qualificada por Luciano MUSSELLI como confusa e desorganizada. ${ }^{91}$ São, com efeito, vinte e quatro exceções ${ }^{92}$ que podem ser identificadas em grupos conforme a razão pela qual as sentenças não passam em julgado. ${ }^{93}$

Luciano Musselli identifica no cinquecento "il momento di maggiore sincretismo ed intercambio tra il diritto canonico e il diritto civile, assistendosi ad un

${ }_{87}$ MUSSELLI, Luciano. Il concetto di giudicato nelle fonti storiche del diritto canonico (dalle origini al XVII ${ }^{\circ}$ secolo). Padova: CEDAM, 1972. p. 83-84.

88 Id. Ibid., p. 79.

89 Id. Ibid., p. 85-86.

90 Id. Ibid., p. 86 e 101.

91 Id. Ibid., p. 95.

92 Confira-se o elenco integral das exceções, em latim, na obra de Luciano Musselli (Il concetto di giudicato nelle fonti storiche del diritto canonico, p. 90-91, nota de rodapé n. 10). Em um dos vinte e quatro casos, destaca oautor, aparece a idéia de que não passa em julgado a sentença proferida com base em provas não muito seguras (MUSSELLI, Luciano. Il concetto di giudicato nelle fonti storiche del diritto canonico (dalle origini al XVII ${ }^{\circ}$ secolo). Padova: CEDAM, 1972. p. 97).

93 Id. Ibid., p. 92. 
singolare processo, per il quale si elabora, ad opera dei processualisti quali appunto il Maranta e lo Scaccia una teoria unitaria del passaggio in giudicato, contemplante dal punto di vista delle eccezioni al principio del 'transitus' oltre a quelle già affermate o direttamente od implicitamente dalla dottrina canonistica anche altre eccezioni di natura propriamente civilistica ed improntate a ragioni diverse da quelle classiche della 'salus animarum' e del 'periculum peccati'", 94

Interessante mencionar que Maranta trata do limite temporal dentro do qual se poderia agir contra a sentença não suscetível de transitar em julgado e estabelece para isso o prazo de trinta anos quando a sentença não implique periculum animarum, hipótese na qual é perpetuamente suscetível de ser modificada. ${ }^{95}$ Por outro lado, deixa de tratar da distinção entre sentenças pró e contra matrimônio relativamente ao trânsito em julgado. ${ }^{96}$

É de se observar o radicalismo de Scaccia ao afirmar que não existia mais a coisa julgada no direito canônico, pois nenhuma sentença canônica passava em julgado. ${ }^{97}$

Não bastasse toda a desconstrução supramencionada durante o cinquecento, o direito canônico, estrutura que era da organização da Igreja católica, sofreria ainda outro golpe decorrente da Reforma. ${ }^{98}$

A Reforma, entretanto, possibilitou à Igreja um esforço no sentido de demonstrar "che il diritto canonico non era strumento di mondanità e di corruzione, ma un mezzo indispensabile per l'organizzazione della società cristiana e la salvezza delle anime" 99 Para atingir tal objetivo, teve a Igreja que se desprender da "herança" do direito romano, pois muitos de seus princípios não respondiam à exigência da espiritualidade cristã. ${ }^{100}$

Foi nesse momento da história que o direito canônico passou por um processo de espiritualização e em meio a esse processo "i dottrinari dello 'jus novum', trarranno tra gli altri, ache l'istituto della sentenza e del giudicato, dalla decadenza e dalla esasperazione casistica del ' 500 ad una maggiormente equilibrata elaborazione scientifica" 101

Excetuando-se o aspecto supramencionado, "la dottrina del Seicento non presenta dal punto di vista formale novità di rilievo di carattere teorico nel campo della 'res judicata', rispetto al filone tradizionale della canonistica classica" ${ }^{102}$ Isso deve-se ao fato

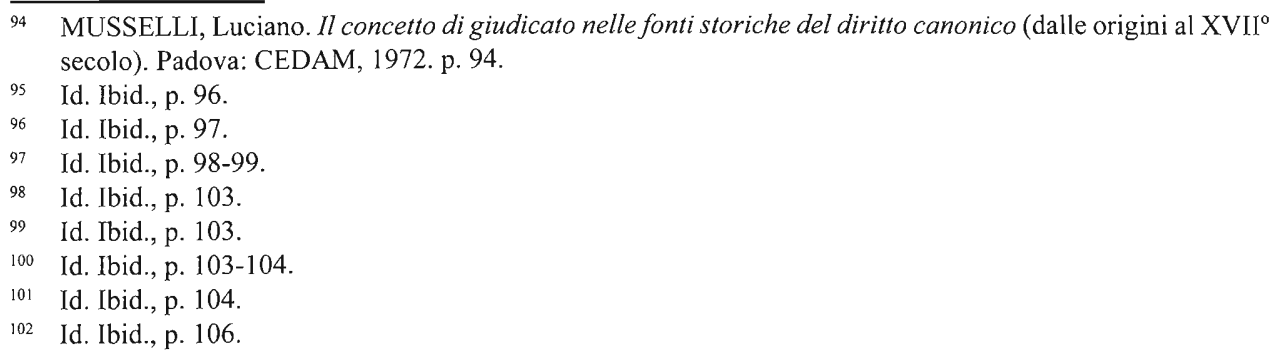


de que "il Seicento, per quanto attiene al diritto canonico, è caratterizato da una riforma metodologica, di origine e natura nettamente controriformistica, che pone in primo piano, e talora al di sopra dei testi e delle concezioni giuridiche, altri testi e concezione di natura squisitamente religiosa" 103

Em razão desse "novo" espírito informador do direito canônico nesse período, passa-se a buscar soluções sempre mais próximas a um ideal cristão de equidade e justiça. Entretanto, nenhum grande avanço houve, como já se disse, na teoria sobre a sentença e a coisa julgada. ${ }^{104}$

Não é possível considerar uniformemente os anos seiscentos como um período de ressurgimento do direito canônico, pois de certa forma a teoria de Pirhing provocou um agravamento da crise do conceito de coisa julgada no direito canônico ao afirmar a possibilidade de retratação do juiz, relativamente às sentenças já proferidas, sem a necessidade dos instrumentos de impugnação extraordinários. Com efeito, essa ampla possibilidade de retratação não é coerente com o conceito de coisa julgada como irrevogabilidade das decisões. ${ }^{105}$

Conclui-se, assim, a exposição das principais passagens históricas que merecem ser destacadas no âmbito da história da coisa julgada no direito canônico. Destaque-se que a inserção do estudo da história no presente trabalho não se dá de forma autônoma, mas instrumental, na medida em que serve ao estudo do direito vigente.

Dar-se-á início, agora, ao estudo da dogmática, ressaltando que será feito um estudo conjunto dos Códigos de Direito Canônico de 1917 e de 1983.

5. Aspectos práticos da coisa julgada no Código de 1917 e no Código de 1983

Retoma-se aqui a premissa de que a coisa julgada é instituto que se situa entre duas exigências: a da segurança e a da certeza (no sentido já explicitado no início do trabalho, de busca pelo resultado mais próximo da verdade). ${ }^{106}$

Nesse sentido, é certo que "in ogni forma di vita associata si impone la certezza della norma quale condizione perchè l'azione umana possa realizzarsi. La

103 MUSSELLI, Luciano. Il concetto di giudicato nelle fonti storiche del diritto canonico (dalle origini al XVII ${ }^{\circ}$ secolo). Padova: CEDAM, 1972. p. 120-121.

104 Id. Ibid., p. 121.

105 Id. Ibid., p. 122.

106 São interessantes as palavras de Elio Mazzacane: "A noi pare che una parola chiarificatrice l'abbia detta il Capograssi laddove egli, pur dando al problema una impostazione di carattere filosofico, ha affermato che 'la certezza come legalità formale c'è anche nell'ordinamento canonico, ma qui la certezza è qualcosa di interno, di sostanziale... è la vera certezza di cui quella formale e legale non è che, alla fine, l'apparizione, la veste esteriore" (MAZZACANE, Elio. Il giudicato canonico e la certezza del diritto. Raccolta di scritti in onore di Arturo Carlo Jemolo. Milano: Giufrrè, 1963. v. 1, t. 2, p. 887). 
certezza si presenta così come elemento costitutivo del diritto perchè certezza del diritto è certezza dell'azione" 107

Abstraindo do conceito filosófico de verdade, o ideal seria que a verdade alcançada no processo fosse idêntica à verdade existente no mundo fático. Entretanto, não é possível uma busca obstinada pela verdade, tendo ela que se equilibrar, na justa medida, com a segurança.

A verdade é valor caro a todas as pessoas em geral, mas ganha maior destaque ainda entre os cristãos, no âmbito do direito canônico. ${ }^{108}$ Para Manuel Jesus Arroba Conde, "pode-se afirmar que, do ponto de vista subjetivo, mesmo tutelando os interesses particulares, o processo canônico não permite rupturas entre o interesse privado e o público, no sentido que todos os participantes do processo (juiz e partes especialmente) estão obrigados a um vínculo de lealdade com relação à verdade objetiva que supera a verdade processual ou formal. Isto condiciona a vigência do princípio segundo o qual as lides não devem durar muito" 109

A exigência da verdade, com efeito, não se encontra presente apenas no instituto da coisa julgada, mas faz-se já presente no estudo da sentença, inegavelmente ligada à coisa julgada, pois a certeza moral é exigência para seu pronunciamento, a teor do cânone 1608 do Código vigente, sendo certo que tal exigência também estava presente no cânone 1869 do Código de 1917. Ainda, a centralidade da certeza moral é apontada por Zenon Grocholewski, como um dos princípios fundamentais do direito canônico. ${ }^{110}$

A certeza moral, entretanto, não pode ser considerada em termos absolutos. Com efeito, "esta certeza no está definida en el derecho; no es una certeza propiamente dicha: porque la sentenza propiamente dicha es la certeza 'filosófica', en cualquiera de sus modalidades (metafísica, física, moral estricta). Esta certeza moral estricta consiste

107 MAZZACANE, Elio. Il giudicato canonico e la certezza del diritto. Raccolta di scritti in onore di Arturo Carlo Jemolo. Milano: Giufrè, 1963. v. 1, t. 2, p. 882. O termo certeza, nessa passagem, é utilizado, como sinônimo de segurança, contrariamente ao sentido adotado neste trabalho.

108 "Si en todos los ordenamientos es esencial la búsqueda de la justicia y la verdad, mucho más aún lo es en el Derecho canônico, en el que la exigencia de concordancia entre la verdad procesal y la verdad real se convierte en un imperativo moral a fin de evitar posibles situaciones de pecado" (ZUBILLAGA, José Luis López. La doble decisión conforme en la doctrina procesal del código de 1917. cit., p. 193). No mesmo sentido, Carmelo de DIEGO-LORA: "en el Derecho canónico, esa preocupación de que la verdad formal responda siempre a la sustancial adquiere uma mayor razón de exigencia cuando, ante determinadas cuestiones sobre todo en relación con la nulidad del matrimonio canónico -, se advierte que una sentencia errónea puede ser fuente de peligro para el alma o poner en grave peligro el sacramento" (DIEGO-LORA, Carmelo de. De la cosa juzgada y de la restitución 'in integrum'. In: MARZOA, A.; MIRAS, J.; RODRÍGUEZOCAÑA, R. (Coord.). Comentário exegético al código de derecho canónico. 2. ed. Pamplona: EUNSA, s/d. v. $4 / 2$, p. 1.678).

109 CONDE, Manuel Jesus Arroba. Direito processual canônico. Trad. por Côn. Dr. Martin Segú Girona. 5. ed. Roma: Institutum Iuridicum Claretianum, 2006. p. 47-48.

110 GROCHOLEWSKI, Zenon. Principios inspiradores del proceso canónico ordinario. Ius Canonicum, Navarra, v. 27, n. 53, enero/jun. 1987. p. 477-479. 
en un convencimiento tan firme que de él está excluído el temor de que sea moralmente posible (pero no el temor de que sea fisicamente posible) lo contrario" "111 Deve ser, em suma, não uma exigência de verdade, mas de uma certeza suficiente para se proceder com prudência. ${ }^{112}$

Frise-se que "a 'certeza" exigida, embora qualificada de 'moral', nada tem de personalíssima ou insindicável" 113 Trata-se de uma "certeza "objetivamente fundada" 114 e que "deve ser extraída daquilo que foi trazido para o processo e está retratado nos autos" 115

Como se vê, a exigência da certeza moral não está ligada, de modo algum, à exigência de busca de uma verdade absoluta, que, caso existisse, tenderia a eternizar o processo. A preocupação com a certeza talvez seja um pouco maior do que nos ordenamentos laicos em razão da salus animarum.

São precisas, nesse sentido, as palavras de Elio Mazzacane: "La pressione di elementi metagiuridici, che non restano alle soglie del diritto canonico, penetrandone invece la struttura, l'influenza di principi religiosi che permeano questo diritto (si pensi alla operatività della equità come fonte del diritto anche nell'ambito del diritto penale, sì che il principio di legalità ne resta neutralizato) impongono il sacrificio della lettera della disposizione in vista della suprema finalità della salus animarum. Il diritto canonico, cioè, per la sua peculiare struttura, per il diverso fondamento rispetto agli ordinamenti statuali, è portato a sacrificare il principio della certezza per soddisfare un principio religioso di diritto divino - l'esigenza della giustizia e della verità obbiettiva - che soppianta l'esigenza della certezza e ne prende il posto. Il contrasto tra giustizia e certezza, motivo ricorrente di tutto il diritto della Chiesa, ponendo di fronte esigenze inconciliabili, si risolve a favore della giustizia in considerazione di principi di diritto divino" 116

Vale reforçar que tudo isso não significa que o instituto da coisa julgada não se faça presente no ordenamento canônico. Pronuncia-se, nesse sentido, mais uma vez, Elio Mazzacane: "Non che questa non esplichi la sua efficacia anche nell'ordinamento processuale canonico. La necessità che la sentenza, quando si siano esauriti i normali

FAÍLDE, Juan José García. Nuevo derecho procesal canónico. cit., p. 217.

112 Id. Ibid., p. 217. Em nota ao cânone 1608 do Código vigente, Pe. Jesús Hortal afirma que "certeza moral é a persuasão produzida no ânimo do juiz, de acordo com o modo normal de agir das pessoas, que exclui qualquer dúvida prudente. Não é o mesmo que certeza absoluta, pois não exclui toda possibilidade de errar. Por isso, costumam-se tomar como sinônimos os termos 'moralmente certo' e 'probabilissimo"' (HORTAL, Jesús. Código de direito canônico. 9. ed. São Paulo: Loyola, 2008. p. 384).

113 TALAMINI, Eduardo. Eficácia e autoridade da sentença canônica. cit., p. 45.

114 Id. Ibid., p. 45.

115 Id. Ibid., p. 45. O juiz não pode se utilizar de conhecimentos próprios dos fatos se eles nâo estiverem provados nos autos. Assim, "quando o juiz detiver conhecimento de elementos relevantes para a decisão, mas ainda estranhos ao processo, caber-lhe-á valer-se de seu poder de determinar a produção de provas de ofício (c. 1600 , esp. $\$ 3^{\circ}$ ), para assim trazer tais dados para o processo e evitar uma sentença injusta" (Id. Ibid., p. 45).

116 MAZZACANE, Elio. Il giudicato canonico e la certezza del diritto. cit., p. 885-886. 
remedi previsti per la sua impugnabilità, sia accompagnata da una presunzione assoluta di rispondenza alla verità ed alla giustizia, sì che essa non possa più essere messa in discussione, sussiste anche nel diritto della Chiesa. È solo quando sussitano particolari motivi che è resa possibile - contro il principio dell'autorità del giudicato - la revisione in ogni momento della pronuncia giudiziale; quando si determini cioè il periculum animae, l'esigenza di salvaguardare il bonum publicum che è la salus animarum, fine primario della Chiesa" 117

Feita essa introdução, vale ressaltar que não se justificam dois estudos completamente apartados do instituto da coisa julgada nos dois Códigos, uma vez que, como restará demonstrado, o instituto recebeu tratamento muito semelhante nos dois diplomas. Com efeito, "el sistema del CIC 17 ha sido trasplantado esencialmente, con variantes sólo secundarias, al sistema procesal del Código de 1983" 118

Assim, muito mais útil abordá-los de forma unitária, apontando as divergências quando existentes.

Por fim, mencione-se que "en la legislación que surgió con posterioridad al Código de 1917 sólo destaca la supresión de la doble conformidad recogida en la norma vigesimotercera concedida a la Conferencia Episcopal de Estados Unidos" 119

\subsection{Coisa julgada - hipóteses de formação}

A enumeração do cânone 1641 do Código Canônico de 1983 é taxativa, assim como era aquela contida no cânone 1902 do Código de 1917.

No Código vigente são quatro as hipóteses em que se dá o trânsito em julgado: (i) se tiverem sido dadas duas sentenças concordes entre as mesmas partes, sobre a mesma petição e pela mesma causa de demanda; (ii) se a apelação contra a sentença não tiver sido apresentada dentro do tempo útil; (ii) se, em grau de apelação, a instância se tiver tornado perempta ou se tiver havido renúncia a ela e (iv) se tiver sido proferida sentença definitiva, contra a qual não se admite apelação, de acordo com o cânone 1629.

O cânone 1902 do Código de 1917 trazia, por sua vez, apenas três hipóteses, quais sejam: (i) existência de duas sentenças conformes; (ii) a ausência de apelação em tempo hábil ou o abandono da apelação e (iii) com apenas uma sentença inapelável.

Como se vê, embora o número de parágrafos contidos no cânone fosse menor no Código anterior, as hipóteses eram exatamente as mesmas, uma vez que a

117 MAZZACANE, Elio. Il giudicato canonico e la certezza del diritto. cit., p. 888.

118 DIEGO-LORA, Carmelo de. De la cosa juzgada y de la restitución 'in integrum'. cit., p. 1706.

119 ZUBILLAGA, José L. López. La doble decisión conforme en la doctrina procesal del código de 1917. cit., p. 191. 
segunda hipótese de formação de coisa julgada prevista no Código de 1917 concentrava as segunda e terceira hipóteses do Código vigente.

O que se percebe é que o Código de 1983, dentro do mesmo espírito do Código anterior, é apenas dotado de um pouco mais de clareza. Nesse sentido, enquanto o Código anterior se limitava a afirmar que se dava a coisa julgada com a dupla conformidade, o atual Código explica - ou tenta explicar - em que consistiria essa conformidade.

Ambos os Códigos, além de disciplinar as hipóteses de formação da coisa julgada, afirmam que nunca passam em julgado as causas relativas ao estado das pessoas. Apesar disso, estabelecem que, havendo a dupla conformidade nessas causas, só se admitirá nova proposta se forem deduzidas novas e graves provas ou argumentos (cânones 1643 e 1644, $\S 1^{\circ}$ do Código vigente e cânone 1903 do Código de 1917, o qual, entretanto, ao menos na versão referida na bibliografia, falava em "nuevas y graves razones o documentos" ${ }^{120}$ ).

A revisão da causa, embora com outro nome - restitutio in integrum - é também possível nas causas não matrimoniais desde que manifesta a injustiça da sentença proferida (cânone 1645). Tal tema, embora interessante, não será aqui aprofundado, porque seu estudo implicaria desvio dos objetivos do presente trabalho.

Por fim, necessário mencionar alguns cânones que disciplinam os processos de nulidade matrimonial, uma vez que tais processos constituem a maior parte dos processos julgados pelos tribunais eclesiásticos.

Destaque-se que as causas matrimoniais são causas que dizem respeito ao estado das pessoas e por isso as sentenças nelas proferidas não transitam em julgado. Entretanto, em tais causas também se fala de dupla conformidade, uma vez que, a teor do cânone 1684 do Código vigente, ela é exigida para a execução da decisão contrária ao vínculo matrimonial. ${ }^{121}$

Essa exigência da dupla conformidade para executar uma sentença de nulidade matrimonial só não existe nos processos documentais (cânone 1686 do Código de 1983). ${ }^{122}$ Esclareça-se que em tais processos não se proíbe a apelação. Ao contrário, ela

120 MORAN, Sabino Alonso; CABREROS DE ANTA, Marcelino. Comentarios al codigo de derecho canónico. Madrid: Editorial catolica, s/d. v. 3, p. 637, destaque nosso.

121 Nunca é demais lembrar que as causas favoráveis ao vínculo matrimonial não demandam execução e por isso não se fala em exigência de dupla conformidade nesses casos.

122 Embora a legislação só excepcione os processos documentais, é fato que "para a eficácia da sentença de nulidade, a morte do cônjuge dispensa a 'dupla conforme' Reputa-se que a ausência de risco de pecado torna sem sentido aquela cautela. Viu-se haver quem discorde desse entendimento, sob o argumento de que o interesse público na defesa do sacramento permaneceria mesmo depois da morte do cônjuge. Mas a tal argumento responde-se que a proteção ao sacramento não é um fim em si mesmo: a ratio sacramenti está indissociavelmente ligada à ratio pecati" (TALAMINI, Eduardo. Eficácia e autoridade da sentença canônica. cit., p. 48-49), mas "nem com a morte de um dos cônjuges a sentença em processo matrimonial fará coisa julgada" (Id. Ibid., p. 49). 
é expressamente permitida pelo cânone 1687 tanto ao defensor do vínculo quanto à parte que se sentir prejudicada.

Necessário observar que o teor do cânone 1644 poderia levar o intérprete a pensar que a exigência de novos e graves argumentos não seria aplicável ao processo documental, no qual não se exige a dupla conformidade. Entretanto, o que libera o processo documental da dupla conformidade é o fortíssimo valor probatório que possui a prova documental. Assim, do mesmo modo que em qualquer causa sobre estado das pessoas, também nos processos documentais de nulidade matrimonial são exigíveis os novos e graves argumentos. ${ }^{123}$

\subsubsection{Dupla conformidade vs. duplo grau de jurisdição - dois institutos diferentes}

Dentre as hipóteses de formação da coisa julgada, merece destaque a relativa à dupla conformidade. Embora exista no processo canônico a figura da sentença inapelável, estranha ao processo civil laico, onde se cultua o princípio do duplo grau de jurisdição, é na dupla conformidade que se encontram as maiores peculiaridades do tema no processo canônico.

Vale ressaltar que a exigência de dupla conformidade não é equiparável, como querem alguns, ${ }^{124}$ ao duplo grau de jurisdição obrigatório existente no ordenamento processual civil laico de alguns países. ${ }^{125}$ Com efeito, não é a dupla conformidade uma mera necessidade formal de a causa passar por duas instâncias diferentes. É muito mais do que isso: em primeiro lugar, a necessidade da dupla conformidade nem sempre se resume a duas instâncias; podem ser necessárias mais de duas. Em segundo lugar, não bastam duas decisões quaisquer, pois há a necessidade de que sejam duas decisões conformes.

Por fim, enquanto no direito laico fala-se em interpor recurso à instância superior, regra geral ${ }^{126}$ não existe essa hierarquia entre os tribunais no direito canônico,

123 Confira-se, nesse sentido, ZUBILLAGA, José Luis López Zubillaga. La conformidad de decisiones en el Código de 1983. cit., p. 697.

124 Nesse sentido, COLOMER, José Francisco Castelló. La doble sentencia conforme: ¿conformidad equivalente o conformidad formal? Roma: Pontifica Università Lateranense, 2003. Excerptum theseos ad Doctoratum in Iure Canonico, p. 10.

125 No Brasil, por exemplo, existe o duplo grau de jurisdição obrigatório, chamado "reexame necessário", quando a sentença não estiver fundada em jurisprudência do plenário do STF ou em súmula do STF ou dos Tribunais Superiores, nas causas que envolvam valor superior a sessenta salários mínimos (I) nas quais é proferida sentença contra a União, o Estado, o Distrito Federal, o Município, e as respectivas autarquias e fundações de direito público ou (ii) que julgarem procedentes, no todo ou em parte, os embargos à execução de dívida ativa da Fazenda Pública (art. 475, incisos I e II e $\$ 2^{\circ}$ do Código de Processo Civil). E a teor da Súmula 45 do STJ, "é defeso, ao Tribunal, agravar a condenação imposta à Fazenda Pública".

126 Essa regra é excepcionada em relação do Tribunal da Rota Romana que possui, quando menos, função de orientador e pode ser considerado superior aos demais. Com efeito, no direito canônico não existe "jerarquía de sabiduría jurídica, salvados los tribunales apostólicos, ya que la pericia jurídica entre un tribunal de primera y segunda instancia, así como la forma de composición del tribunal, son en ambos casos semejantes 
de modo que se exige a dupla conformidade em razão do fato de se buscar duas decisões diferentes para garantir um maior acerto e não a revisão da decisão de primeira instância pela segunda instância.

5.2. Sentenças que não transitam em julgado: as causas de estado ${ }^{127}$

Como já dito acima, prevê o Código vigente - tal como previa o Código de 1917 - que não transitam em julgado as causas relativas ao estado das pessoas.

Dentre as causas relativas ao estado das pessoas incluem-se, como não poderia deixar de ser, as causas de nulidade matrimonial e, a partir de 1983, por disposição legal expressa, as causas de separação dos cônjuges.

O pensamento tradicional, resultante de uma interpretação literal da lei, é bem explicitado nas palavras de Andrea Bettetini: "queste sentenze, ai sensi di un diritto che, come vedremo, è riflesso di una lunga tradizione, non raggiungono mai la stabilità propria della cosa giudicata, sebbene possano produrre taluni specifici effetti del giudicato. Invero, nel caso di doppia sentenza conforme la possibilità di un ulteriore grado di giurisdizione è limitata alla presentazione, quale causa giustificativa dell'azione (fumus boni iuris), di nuove e gravi prove e argomenti. Detto altrimenti, la sentenza sarà ferma, e produttiva di effetti giuridici fra le parti, sino a che la giustizia non richieda, per il bene delle anime e della Chiesa, che la causa sia revista; ma ciò si darà solo in presenza di nuovi e gravi elementi probatori non considerati dal giudice che ha emesso la sentenza, sì da poter parlare in materia matrimoniale, come di fatto la Rota stessa ha fatto, di res $<<$ quasi-iudicata $>>$, di una condizione processuale assimilabile alla res iudicata" ${ }^{128}$

y, por tanto, no se trata tanto de un juicio superior sino más bien de un juicio diverso" (ZUBILLAGA, José Luis López. La doble decisión conforme en la doctrina procesal del código de 1917, op. cit., p. 138).

127 São causas sobre o estado da pessoa "aquellas que directamente miran a la identidad o estado de las mismas $o$, en general, circa iura familiae. Tales son aquellas en las que se ventilan si uno es clérigo, religioso, si está casado legítimamente, si es hijo legítimo, si está separado legitimamente de su esposa, si es extranjero, peregrino, etc. Tales causas gozan de acción imprescriptible por hallarse tan íntimamente unidas a la persona como la lepra a la piel, según gráficamente dice LEGA-B (c. 1701)" (HERNÁNDEZ, Miguel Moreno. Derecho procesal canónico. Madrid: Aguilar, 1956, p. 336-337). Fernando Della Rocca é um pouco mais técnico na definição afirmando que sentenças proferidas em causas de estado são "sentencias relativas al vínculo matrimonial, a la ordenación y a la profesión religiosa, y en general en todas las sentencias limitativas de la libertad procesal (p. e. la interdición), salvo, como es obvio, las que versan sobre relaciones dependientes de naturaleza puramente econômica" (DELLA ROCCA, Fernando. Instituciones de derecho procesal canónico. Buenos Aires: Desclée de Brower, s/d. p. 363-364). Por fim, de acordo com Eduardo Talamini, "Há na doutrina canônica a tendência de adotar uma concepção ampla de status personarum, que compreende: a) o status civitatis (direitos essenciais do homem, sua liberdade, capacidade...); b) o status religionis (o estado jurídico dos fiéis, dos religiosos, dos clérigos e os direitos espirituais essenciais a esses estados); c) o status familiae (filiação, matrimônio...)" (TALAMINI, Eduardo. Eficácia e autoridade da sentença canônica. cit., p. 39).

128 Verità, giustizia, certezza, op. cit., p. 20-21. No mesmo sentido, Manuel Jesus Arroba Conde afirma que "devendo prevalecer sempre a verdade objetiva sobre a formal certeza jurídica da 'res iudicata' nas causas do 
Afirmou diversas vezes José Rogério Cruz e Tucci, durante as aulas do curso de pós-graduação, ${ }^{129}$ que acredita haver coisa julgada nas causas sobre o estado das pessoas uma vez que as exigências para o reexame da causa constituiriam novas causas de pedir e, portanto, o reexame seria uma nova ação.

Embora pareça acertada, como procurar-se-á demonstrar, a afirmação de que as causas de estado transitam em julgado, é possível, com todo o respeito, discordar daquela segundo a qual as exigências do Código denotam a dedução de uma nova causa de pedir. O Código de Direito Canônico é expresso ao afirmar que são exigidas novas e graves provas ou argumentos. O termo argumentos, em razão de sua amplitude, pode até dar ensejo à afirmação de que se exige uma nova causa de pedir. Entretanto, a apresentação de novas provas pode dar-se dentro da mesma causa de pedir anteriormente deduzida.

E parece acertada a opinião de que sequer os novos argumentos constituem novas causas de pedir. De acordo com José Luis López Zubillaga, "la referencia a esos nuevos argumentos nunca debe entenderse en el sentido de la alegación de un nuevo capítulo de nulidad, ya que eso supondría la introducción de una causa completamente nueva porque la causa petendi será totalmente diferente a la decidida anteriormente. En cualquier caso la alegación de esas nuevas pruebas exigirá un juicio previo acerca de la importancia e novedad de las mismas" 130

Eduardo Talamini, reunindo os dois entendimentos, manifesta-se no sentido de que "a rigor, nem mesmo fatos novos precisam ser apresentados. A revisão pode tomar em conta fatos anteriormente indicados, mas que não foram suficientemente provados ou

estado das pessoas existem garantias menores de firmeza e consente-se o novo exame a partir do momento que surjam novos elementos, apesar da dupla conformidade das decisões" (CONDE, Manuel Jesus Arroba. Direito processual canônico, op. cit., p. 672). Ainda, José Carlos Barbosa Moreira afirma que "concebe-se a existência de ordenamento em que as sentenças, ou algumas delas, sejam indefinidamente passíveis de verse anuladas, modificadas no todo ou em parte, ou simplesmente substituídas por outras de conteúdo igual, quer se permita esse resultado pela multiplicação ilimitada no número de recursos, quer pela outorga de liberdade ao juiz para, noutro processo, voltar a decidir, de maneira idêntica ou não, aquilo que já se decidira no anterior. Parece que se podem apontar exemplos históricos de sistemas jurídicos com essa característica; e, mesmo em nosso tempo, deparam-se manifestações ao menos parciais do fenômeno: assim, no direito canônico sujeitam-se a uma série em princípio indefinida de reexames as causas relativas ao estado das pessoas" (MOREIRA, José Carlos Barbosa. Eficácia da sentença e autoridade da coisa julgada. In:

Temas de direito processual. São Paulo: Saraiva, 1984. Terceira série, p. 101). Ver, por fim, José Luiz López ZUBILLAGA: "conviene distinguir entre la cosa juzgada y el pleito acabado. La primera tiene un sentido más amplio, ya que no todo pleito acabado es cosa juzgada, aunque toda cosa juzgada supone un pleito acabado. En las causas que concluyen por sentencia firme, pero que no pasan a cosa juzgada, como las del estado personal habría que hablar de pleito acabado pero no de cosa juzgada" (ZUBILLAGA, José Luiz López. La doble decisión conforme en la doctrina procesal del código de 1917. cit., p. 134).

129 Aulas ministradas na disciplina História do Processo Civil Romano, Canônico e Lusitano: história do processo canônico, do curso de pós-graduação stricto sensu da Universidade de São Paulo, $2^{\circ}$ semestre de 2010.

130 ZUBILlaGA, José Luiz López. La doble decisión conforme en la doctrina procesal del código de 1917. cit., p. 150. 
considerados. Exige-se apenas que as provas ou argumentos em relação a tais fatos sejam novos. Mas nada impede que, com a prova ou argumento novo, seja efetivamente trazido também um fato novo. Isso pode acontecer sem que signifique a adução de uma causa de pedir nova. Basta que seja um fato secundário, integrante da (ou relevante para a) causa de pedir antes posta" 131

Voltando ao tema do trânsito em julgado da sentença nas causas de estado, afirma José Luis López Zubillaga que acredita ser "fundado en la práctica procesal el hecho de que todas las causas, incluso las del estado personal admiten el efecto de cosa juzgada formal directamente ligado, al menos, a la doble conformidad de decisiones" 132

Com efeito, obtida uma dupla conformidade, não mais será possível o manejo do recurso ordinário ( $v . g$. apelação) contra aquela decisão. Admite-se a nova proposição da causa, mas não há como negar - justamente porque se trata de uma nova proposição - a formação da coisa julgada formal.

Nada há de incompatível, portanto, entre a formação da coisa julgada formal e ampla possibilidade de revisão do conteúdo da sentença proferida. Nesse sentido, a demonstrar a amplitude referida, tem-se que a revisão da sentença de nulidade matrimonial "será possível mesmo depois da integral produção de efeitos concretos pela sentença. Assim, declarado nulo o casamento mediante 'dupla conforme', em princípio às partes é dado contrair novas núpcias (c. $1684, \S 1^{\circ}$ ). Caso o façam, se depois a sentença de nulidade vier a ser revista, considerando-se perfeito o casamento antes tido por nulo, os novos vínculos matrimoniais ficarão sem efeito, tornando a vigorar o anterior" 133 Quando isso ocorrer, "ficarão resguardadas as obrigações de auxílio ao cônjuge e à prole, derivadas dessas novas núpcias (alimentos etc.), conforme o cânone 1689" "134 Isso causa perplexidade, sem dúvida. Por outro lado, impedir a revisão da causa após a contração de novas núpcias, contrariaria o fundamento do ordenamento canônico.

Interessante observar ainda que "sendo a finalidade da norma, nas ações matrimoniais, evitar o pecado, admite-se que o próprio vencedor da causa anterior esteja

131 TALAMINI, Eduardo. Eficácia e autoridade da sentença canônica. cit., p. 42. Ressalte-se, entretanto, que "não se concebe, porém, a pura e simples reavaliação das provas - o que transformaria o pedido de revisão em simples recurso ordinário equiparável à apelação, já preclusa. A argumentação nova que justifica o reexame da causa é aquela que aponta para uma ostensiva lesão à justiça ou à verdade (...). É possível inclusive que a nova argumentação não verse sobre aspectos fáticos, mas estritamente jurídicos (...). Admitese como argumento novo e grave até mesmo a alegação de violação a normas processuais - o que não é possivel, por exemplo, na restitutio in integrum" (Id., p. 43).

132 ZUBILLAGA, José Luis López. La conformidad de decisiones en el Código de 1983. cit., p. 660.

133 TALAMINI, Eduardo. Eficácia e autoridade da sentença canônica. cit., p. 39.

134 Id, Ibid., p. 40. 
legitimado a pleitear a revisão" ${ }^{135}$ Com efeito, "para o pedido de revisão da causa não vigora a proibição do venire contra factum proprium" 136

José Luis López Zubillaga vai além e defende, inclusive, a formação de coisa julgada material (quando, esclareça-se, é alcançada a dupla conformidade) nas causas de estado. Nesse sentido, "si una sentencia de nulidad matrimonial, por ejemplo, puede ejecutarse y los esposos cuyo matrimonio fue declarado nulo tras dos decisiones conformes pueden acceder a nuevas nupcias, podemos afirmar con rotundidad que el efecto material de la cosa juzgada se ha producido plenamente en una causa del estado personal (...)" ${ }^{137}$ No entanto, sua concepção de coisa julgada material, do que se extrai da passagem citada, é diferente da concepção da doutrina majoritária, pois o fato de a sentença poder produzir plenamente seus efeitos em nada depende da formação da coisa julgada material que é, isso sim, imunização desses efeitos.

Mas, ainda que se adote aqui concepção de coisa julgada material diversa da do autor, conclui-se que há formação de coisa julgada, pois essa possibilidade de revisão da sentença pode ser vista como algo similar a uma ação rescisória do processo laico, mas sem prazo (e a ação rescisória, como é sabido, é justamente uma maneira de impugnar a sentença transitada em julgado). Assim, "la nueva proposición de la causa cumple, respecto a las causas del estado personal, la misma función que la restitutio in integrum respecto a cualquier otro tipo de causa. En definitiva, ambos son medios impugnatorios de una causa que ha pasado a cosa juzgada" 138

135 TALAMINI, Eduardo. Eficácia e autoridade da sentença canônica. cit., p. 49.

136 Id. Ibid.

137 ZUBILlaGA, José Luis López. La conformidad de decisiones en el Código de 1983. cit., p. 660. O problema, que será detalhado adiante, está no fato de que uma das hipóteses de formação da coisa julgada é também requisito para produção de efeitos da sentença proferida contra o vínculo matrimonial (a dupla conformidade), o que gera alguma confusão na doutrina Necessário, aqui, estudar, ainda, a questão de haver uma única sentença a favor do vínculo matrimonial. Se acreditarmos que as sentenças proferidas em causas sobre o estado das pessoas não transitam em julgado, teríamos que admitir, a qualquer tempo, apelação contra referida sentença. Vale transcrever os questionamentos apresentados pelo jurista espanhol: "El problema surge en el aspecto formal de la cosa juzgada. ¿Es posible impugnar en cualquier momento mediante apelación esa primera sentencia a favor del vínculo? Si damos preponderancia al canon $1641,2^{\circ}$ habría que decir que no es posible, ya que para impugnarla sería necesario emplear el medio extraordinario del canon 1644, es decir la nueva proposición de la causa. Pero este canon sólo menciona como motivo previo para la posible concesión de la nueva proposición el hecho de haberse producido dos sentencias conformes en esa causa, evidentemente tanto a favor como en contra del vínculo. ¿Esto significa que sólo es posible emplear este medio impugnatorio en ese caso o también en los demás supuestos del canon 1641?" (Id., p. 662).

138 ZUBILlAGA, José Luis López. La conformidad de decisiones en el Código de 1983. cit., p. 661. Não se está aqui querendo defender, é bom esclarecer, a força absoluta das sentenças canônicas indistamente. Com efeito, "la fissità di una sentenza non è tuttavia assoluta, e non può in vertià esserlo. L'inadeguatezza di una firmitas incondizionata deriva innanzitutto da un'evidenza di senso comune. Che cioè l'intelligenza e la volontà umane sono defettibili. E così se la ricerca del giudice ha ad oggetto la verità, è indubbio che egli in questa ricerca si può perdere, e di fatto non di rado si perde. Non a caso, già il diritto canonico classico con grande senso del realismo affermava che "veritas sepius exagitata magis splendescit in lucem'" 
Embora desempenhem a mesma função, mister reconhecer que há diferença entre a restitutio in integrum e a nova proposição da causa no sentido de que os motivos para a concessão desta última são muito mais flexíveis, favorecidos que são pelo princípio maior - um verdadeiro sobreprincípio - do direito canônico: a salus animarum.

Para o desenvolvimento do tema relativo ao trânsito em julgado das sentenças nas causas de estado partiu-se de uma passagem de Andrea Bettetini, segundo a qual não haveria trânsito em julgado nesses casos. Entretanto, justiça seja feita ao canonista porque, embora utilize nomenclatura não muito adequada, qual seja "quase coisa julgada" ele reconhece a similitude de regimes relativos aos recursos extraordinários aos quais estão sujeitas as causas comuns e as relativas sobre o estado das pessoas e questiona-se "se in realtà non vi sia un único genere di 'cosa giudicata' di cui partecipano in modo diverso sia le cause sulla condizione giuridica dei sogetti sia le cause da queste diverse; ovvero, in modo più attento alla letteralità del testo normativo e alla tradizione canonistica, se l'eccezione nel diritto della Chiesa sia rappresentata non tanto dalla revocabilità delle cause matrimoniali e per estensione di quelle spirituali e di stato, quanto piuttosto dall'indiscutibilità di quanto si è deciso, non solo per un datto di fatto, e cioè che l'assoluta maggioranza delle sentenze emesse da organi giurisdizionali ecclesiastici sono appunto in materia matrimoniale, e quindi sono sentenze di status; ma soprattutto per l'insuperabile limite posto dal diritto divino alle ragioni di opportunità e sociali che giustificano il giudicato nel diritto secolare" 139

Conclui-se que, a despeito do texto legal, as sentenças em causas sobre o estado das pessoas transitam em julgado sempre formalmente e também materialmente nas hipóteses em que se alcançar a dupla conformidade.

Nesse sentido, é categórica afirmação de Carmelo de Diego-Lora: "también en las causas sobre el estado de las personas se produce el efecto de cosa juzgada, tanto en su dimensión de cosa juzgada formal como en la de la cosa juzgada material, si bien ésta debe ser considerada limitada a la luz de los cc. 1643 y 1644" 140

(BETTETINI, Andrea. Verità, giustizia, certezza... cit., p. 17). O que se quer dizer é que não parece haver ausência absoluta de trânsito em julgado nas causas de estado e que as causas "comuns" são também revisáveis. Vale conferir ainda as palavras de Carmelo de Diego-Lora: "el c. 1643, más que contener un precepto imperativo que niegue de modo absoluto que la cosa juzgada se dé em las sentencias definitivas firmes dictadas em las causas sobre el estado de las personas, há de ser interpretado a la luz del c. 1644. Y en este último canon se advierte que esa cosa juzgada, más que negada queda sometida a una limitación, que se apoya en una determinada eventualidad, la cual, de darse, dejará sin el efecto característico de cosa juzgada a la sentencia que, desde su firmeza, ya la había alcanzado. Desde otro punto de vista, de modo análogo, toda sentencia definitiva firme, excepto las que se dictaron en causas sobre el estado de las personas, está sometida a otra limitación que la condiciona: que se produzca un evento de los previstos en el c. 1645, para que el efecto de cosa juzgada ya producido llegue a ser legítimamente revocado" (DIEGO-LORA, Carmelo de. De la cosa juzgada y de la restitución 'in integrum'. cit., p. 1681).

140 DIEGO-LORA, Carmelo de. De la cosa juzgada y de la restitución 'in integrum' cit., p. 1689, destaques no original. 
Não fosse assim, ou seja, se não transitassem mesmo em julgado as causas sobre o estado das pessoas, caberia, por exemplo, apelação das sentenças proferidas a favor do vínculo matrimonial - as quais, frise-se, não exigem a dupla conformidade porque não demandam execução - a qualquer tempo, o que não é verdade. ${ }^{141}$

As sentenças a favor do vínculo matrimonial transitam em julgado pelo decurso do prazo para apelação. E isso só não ocorre com as sentenças contrárias ao vínculo porque há previsão de apelação de ofício. No processo documental, entretanto, uma única sentença, mesmo contrária ao vínculo, transita em julgado se não houver apelação.

Nem se alegue que o princípio da não passagem em julgado visa a resguardar a salus animarum ou a proteção do bem público da Igreja. ${ }^{142}$ A salus animarum e o bem público da Igreja estão devidamente resguardados com a possibilidade de se reexaminar a causa, o que não impede que se reconheça a existência da coisa julgada.

\subsection{Aspecto bifronte da dupla conformidade}

Muitas vezes foi mencionada neste trabalho a expressão "dupla conformidade" sem esclarecer exatamente em que essa exigência consiste.

A dupla conformidade, como restará demonstrado, tem particular relevância nas causas de nulidade matrimonial. Entretanto, antes de adentrarmos essa seara, é necessário um esclarecimento preliminar.

A exigência de dupla conformidade pode ser estudada sob dois aspectos. O primeiro deles é aquele definido no cânone 1641 de acordo com o qual a dupla conformidade é uma das hipóteses de formação da coisa julgada, significando, assim, a impossibilidade de manejo dos recursos ordinários após a pronúncia de duas sentenças conformes.

141 Confira-se, a esse respeito, o que diz José Luis López Zubillaga: "El problema surge en el aspecto formal de la cosa juzgada. ¿Es posible impugnar en cualquier momento mediante apelación esa primera sentencia a favor del vínculo? Si damos preponderancia al canon $1641,2^{\circ}$ habría que decir que no es posible, ya que para impugnarla sería necesario emplear el medio extraordinario del canon 1644, es decir la nueva proposición de la causa. Pero este canon sólo menciona como motivo previo para la posible concesión de la nueva proposición el hecho de haberse producido dos sentencias conformes en esa causa, evidentemente tanto a favor como en contra del vínculo. ¿Esto significa que sólo es posible emplear este medio impugnatorio en ese caso o también en los demás supuestos del canon 1641?" (ZUBILLAGA, José Luis López. La conformidad de decisiones en el Código de 1983. cit., p. 662). Ainda assim, afirma que a doutrina diverge entre (I) apontar que como não se forma coisa julgada é cabível apelação e (ii) apontar que há nova proposição da causa mas sem as exigências do cânone 1644 (Id., p. 662).

$1+2$ Nesse sentido, cf. DELLA ROCCA, Fernando. Il privilegio delle cause matrimoniali in ordine alla cosa giudicata nel diritto canonico. In: . Saggi di diritto processuale canonico. Padova: CEDAM, 1961. p. $37-40$. 
Por outro lado, a dupla conformidade pode ser, nas causas matrimoniais contrárias ao vínculo, uma exigência para sua execução. ${ }^{143}$ É o que dispõe o cânone 1684 do Código vigente.

Esse aspecto bifronte é perfeitamente traduzido por José Luis López Zubillaga quando afirma que "la doble conformidad tiene, según se trate de la apelación de las partes de una causa o de la que impone la ley en algunos casos como en las causas de nulidad matrimonial, un aspecto diferente. En el primer caso supone una objetiva limitación de las posibilidades apelatorias de las partes por considerar que la justicia y veracidad de la causa están suficientemente garantizadas si dos tribunales coincidieron en su decisión. En el otro caso se trata de buscar el perfeccionamiento de la primera decisión con otra decisión semejante" 144

A busca de aperfeiçoamento a que faz referência não é uma busca subjetiva, mas objetivamente exigida pela lei para que os conjuges que tiveram seu casamento anulado possam contrair novas núpcias.

\subsection{As causas de nulidade matrimonial - causas de estado com regime específico ${ }^{145}$}

Um estudo mais detalhado da coisa julgada nas causas de nulidade matrimonial é justificável não apenas pelo regime particular que nelas apresenta, mas também pelo fato de que a maioria das causas julgadas pelos tribunais eclesitásticos é de nulidade matrimonial.

Tendo em consideração que nas causas de nulidade matrimonial não pode haver execução da sentença contrária ao vínculo antes que seja alcançada a dupla

143 De acordo com Francesco SALERNO, "la necessità di una doppia sentenza conforme per la dichiarazione della nulità del matrimonio canonico è stata voluta (...) da Benedetto XIV, che ha stabilito il principio: "unica sententia super eadem nullitate pronunciata minime sufficiat ad tribuendam liberam coniugibus facultatem novas nuptias contrahendi... nolentes omnino ut ullo in casu matrimonii vinculum dissolutum censeatur nisi duo iudicata, vel resolutiones, aut sententia penitus similes, et conformes, a quibus neque pars, neque defensor matrimonii crediderit appellandum': imponendo al defensor matrimonii l'obbligo di appellare contro la sentenza affermativa di prima istanza al fine di evitare 'nimiam iudicum praecipitantiam in nullitate matrimonii declarada', ed ha reforzato lo stesso principio esigendo: 'in causis matrimonialibus Poloniae, tum prima ab episcopabilus, tum secunda a metropolitanis curiis sententia, super nullitate pronuntiata, executione minime demandetur, nisi utraque sententia, cum rationum momentis, prius in Congregatione... Cardinalium Concilii Tridentini Interpretum mature exacteque fuerit expensa, ac probata' con la sanzione della nulità del matrimonio che fosse stato contratto prima dell'approvazione della medesima Congregazione" (SALERNO, Francesco. La doppia sentenza conforme nel processo matrimoniale canonico: ipotetici precedenti medievali. In: BONNET, Piero Antonio; GULLO, Carlo (a cura di). Verità e definitività della sentenza canonica. Città del Vaticano: Libreria Editrice Vaticana, 1997, p. 9).

ZUBILLAGA, José Luis López. La doble decisión conforme en la doctrina procesal del código de 1917. cit., p. 194.

145 Para histórico do princípio da não passagem em julgado das sentenças proferidas nas causas de nulidade matrimonial, v. DELLA ROCCA, Fernando. Il privilegio delle cause matrimoniali in ordine alla cosa giudicata nel diritto canonico. cit., p. 1-40. 
conformidade - excetuada, como já dito acima (item 5.1 supra), a hipótese do processo documental ${ }^{146}$ - a primeira pergunta que vem à mente de quem estuda o tema é: o que ocorre se não houver apelação?

Na vigência do Código de 1917 havia apelação obrigatória do defensor do vínculo, existente desde a Constitutio 'Dei miseratione', o que causava certa polêmica, pois tinha obrigação de apelar ainda que contrariamente à sua convicção. O regime da apelação obrigatória sofreu parcial alteração com “el 'motu proprio' Causas matrimoniales" que estabelecia "en la norma VIII, §2, que una vez apelada la primera decisión contra el vínculo, en el tribunal de segunda instancia el defensor del vínculo debía manifestar en sus observaciones si tenía que oponer algo o no a la decisión de primera instancia" 147

Nesse ponto, maior inovação mesmo foi a trazida pelo Código de 1983, que substituiu a apelação obrigatória do defensor do vínculo pela remessa da causa ex officio à outra instância. ${ }^{148}$

Vale ressaltar a crítica de Manuel Calvo Tojo que, embora afirme ser louvável o fim da exigência da apelação obrigatória por parte do defensor do vínculo, acredita ter o Código vigente dado um importantíssimo passo atrás "al asumir la ley el papel de apelante frente a toda sentencia afirmativa de primer grado" 149 Propõe como solução que as causas matrimoniais sejam de instância única. ${ }^{150}$

Acredita ainda o jurista ser intolerável a parcialidade da lei ao determinar a apelação de ofício apenas em relação às sentenças afirmativas. ${ }^{151}$

Ainda sobre a apelação de ofício, afirma José Luis López Zubillaga que "el canon 1682 introduce una figura bastante irregular procesalmente, pero que sólo puede justificarse en virtud de ese omnipresente favor veritatis que busca que las decisiones, en este caso de nulidad matrimonial, sean justas y veraces. Esa figura que introduce dicho canon es la 'apelación de ofício' por la que el mismo tribunal que emitió la primera decisión eleva ésta al superior con el fin, no tanto de que el tribunal superior reforme la decisión precedente, como ocurre normalmente en cualquier apelación aunque esto es

\footnotetext{
146 Esclareça-se aqui que a sentença proferida em processo documental, quer a favor, quer contrária ao vínculo, é apelável. Apenas não há exigência de dupla conformidade para sua execução.

147 ZUBILLAGA, José Luis López. La conformidad de decisiones en el Código de 1983. cit., p. 685.

148 Oportuno transcrever, nesse ponto, interessante observação de José Luis López ZUBILLAGA: "No compartimos la opinión de algún autor [M. L. Jordan] que afirma que la institución de la doble conformidad creada juntamente con la del defensor del vínculo por §Benedicto XIV en la Constitución Apostólica Dei miseratione, estaban íntimamente unidas de forma que no podría sobrevivir una sin la outra. A juicio de este autor, desaparecida la apelación obligatoria del defensor del vínculo debiera desaparecer también la doble conformidad ya que ésta no era considerada en si misma sólo a través del defensor del vínculo" (ZUBILlaGA, José Luis López. La conformidad de decisiones en el Código de 1983. cit., p. 687).

149 TOJO, Manuel Calvo. Reforma del proceso matrimonial anunciada por el Papa. Salamanca: Publicaciones Universidad Pontificia, 1999. p. 342.

150 Id. Ibid., p. 351.

151 Id. Tbid., p. 342.
} 
también posible, sino más bien para que confirme la decisión precedente como una forma concreta de garantía de busqueda de esa verdad objetiva que se impone en el proceso canônico" 152

A posição de José Luis López Zubillaga é menos incisiva que a de Manuel Calvo TOJO, pois embora reconheça a irregularidade processual da apelação de ofício, consegue enxergar uma justificativa para ela: o favor veritatis.

É possível que a confirmação da sentença para fins de se alcançar a dupla conformidade se dê por meio de um procedimento abreviado com a promulgação de um decreto (Código vigente, cânone $1682, \S 2^{\circ}$ ). No entanto, a denominação decreto é muito criticada na doutrina, uma vez que o ato desempenha o papel de verdadeira sentença. Tanto isso é verdade que o cânone $1684, \S 2^{\circ}$, prevê que "devem-se observar as prescrições do cân. 1644, mesmo se a sentença que declarou a nulidade do matrimônio não tenha sido confirmada por uma segunda sentença, mas por decreto".

Assim, nas palavras de José Luis López Zubillaga, "cuando se admite la confirmación tras ese proceso abreviado, no parece adecuado llamar 'decreto' a la decisión que viene a confirmar la sentencia de nulidad de primera instancia y a concederle la firmeza y definitividad que la cosa juzgada, aunque sólo sea relativamente, otorga a una doble conformidad. A nuestro juicio, hubiese sido mucho más correcto procesalmente llamar 'sentencia' a esa decisión que resuelve el proceso abreviado. Este término indica de por sí el aspecto definitivo de la decisión que en este caso es lo esencial, mientras que el término 'decreto’ es más propio de las causas incidentales que pueden ser revisadas en la sentencia definitiva y dependen en todo de la causa principal" ${ }^{153}$ Complementa a idéia o autor afirmando que bastaria adicionar um qualificativo ao termo 'sentença', formando a expressão "sentença confirmatória" 154

Por fim, vale lembrar que a exigência da dupla conformidade pode originar alguns casos polêmicos.

O primeiro deles é o caso em que se obtém, após duas sentenças conformes contra o vínculo matrimonial, em nova proposição da causa, uma sentença a favor do vínculo. Se ninguém apela de tal decisão (e não há aqui remessa de ofício, pois a sentença foi favorável ao vínculo), teríamos uma só sentença que pode não ter eficácia frente à dupla conformidade anterior. ${ }^{155}$ Nesse caso, seria o caso de se adotar o conceito de gravame mais

152 ZUBILLAGA, José Luis López. La conformidad de decisiones en el Código de 1983. cit., p. 670.

153 Id. Ibid., p. 692.

154 Id. Ibid., p. 693.

155 Esclareça-se que a dupla conformidade não é exigida quando uma única sentença é proferida a favor do matrimônio. O mesmo não parece ocorrer, entretanto, quando tal sentença é proferida após uma dupla conformidade contrária ao vínculo. Nesse sentido, confira-se o que diz Carmelo de Diego-Lora a respeito da decisão proferida na nova proposição da causa: "Si son coincidentes los resultados lógicos que se deducen de ellas, no cabrá juzgar de nuevo sobre ese estado de las personas sometido al proceso, que ya quedo 
amplo dos germânicos e permitir a apelação daquele que foi beneficiado pela decisão a favor do vínculo.

Com efeito, como afirma José Luis López Zubillaga, "el concepto de gravamen tiene en la doctrina germánica un sentido más amplio. Así, el gravamen podría consistir en esencia en la ausencia del logro fundamental que la parte pretendía. Si entendiésemos así el gravamen sería factible que la parte que pide la revisión de la causa tras una doble conformidade contra vinculo, y obtiene ahora una sentencia pro vinculo pudiese apelar esa decisión con la finalidad de obtener lo que realmente pretende: una doble sentencia conforme pro vinculo que eliminase el efecto de las anteriores. Tampoco ha faltado quien entiende que la propia necesidad de la doble conformidad es ya de por sí un gravamen para quien ha obtenido una sentencia de nulidad matrimonial, por ejemplo" 156

Ainda de acordo com ele, "lo más lógico sería que dicho ministerio público, el defensor del vínculo en los casos de una primera decisión contra vinculo, tras la concesión de la revisión en las causas del estado personal que no sean de nulidad de matrimonio, y el promotor de justicia en el caso de una sentencia pro vinculo en cualquier caso, apelasen dicha decisión a fin de que se obtenga la doble conformidad que permita saber si la revisión concedida tenía o no razón de ser, y si se podía justificar una decisión contraria o no a la doble conformidad anterior" 157

No sentido de "ampliar" o que se entende por sucumbência, tem-se que Manuel Calvo Tojo acredita "que incluso la parte que resulte 'vencedora' en el proceso matrimonial estaria legitimada para la apelación si esa sentencia diere unas razones - las fácticas sobre todo - que tal consorte crea que de esas razones se le pueda irrogar um perjuicio; piénsese, por ejemplo, en el vetitum prevenido en el c. 1684 " 158

O segundo caso polêmico que merece destaque consiste em saber se duas decisões de uma mesma instância podem configurar a dupla conformidade exigida pela lei canônica. José Luis López Zubillaga assim se manifesta: "Nos podríamos plantear si se podría hablar de conformidad en el caso de que en primera instancia se declarase la nulidad por un capítulo, y éste no se confirmase en apelación de oficio, y si volviese a pedir la nulidade del mismo matrimonio por otro capítulo interconectado com aquel y ésta se concediese basándose en los mismos hechos jurídicos. Si esto ocurriese y el nuevo

definitiva y firmemente resuelto, por lo que resultará confirmado simplemente el acierto de la resolución anterior; por lo el contrario, si no se dan esas coincidencias, entonces habrá de emitirse un nuevo juicio sobre lo ya juzgado, sobre aquel objeto primero del proceso, a la luz de una nueva prueba que se muestra prima facie como de valor trascendental a efectos de dictar sobre el caso concreto una futura sentencia de posible contenido distinto del anterior" (DIEGO-LORA, Carmelo de. De la cosa juzgada y de la restitución 'in integrum' cit., p. 1683).

I56 ZUBILLAGA, José Luis López. La conformidad de decisiones en el Código de 1983. cit., p. 667-668.

157 Id. Ibid., p. 668.

158 TOJO, Manuel Calvo. Reforma del proceso matrimonial anunciada por el Papa. cit., p. 340. 
capítulo tampoco hubiese sido confirmado en la apelación de oficio, ¿existió conformidad de sentencias entre ambos capítulos reconocidos en primera instancia? A nuestro juicio no hay tal conformidad. No la habría porque lo que se exige en la ley para la misma en las causas matrimoniales es una doble decisión en distinta instancia, sea ésta por doble sentencia o por sentencia y decreto, y evidentemente referidas al mismo proceso, y a la misma acción por tanto" 159

A dúvida é inquietante uma vez que, regra geral, não existe hierarquia entre as instâncias no direito canônico.

Por fim, o terceiro caso polêmico: é necessária a dupla conformidade nas sentenças da Assinatura Apostólica?

Em primeiro lugar, não se pode confundir o Papa com a Assinatura Apostólica. As sentenças do Papa são inapeláveis, mas as sentenças da Assinatura Apostólica, embora em geral não sejam apeláveis normalmente em razão de sua função de tribunal de cassação, podem ser apeladas. Sendo caso de apelação, esta deve ser apresentada para outra turma do mesmo tribunal. Caso não seja alcançada a dupla conformidade, é necessário solucionar o problema referente a qual sentença prevalece: alguns autores, afirma José Luis López Zubillaga, defendem, garantido o duplo grau de jurisdição, a prevalência da segunda sentença da Assinatura, ainda que não conforme. ${ }^{160}$

\subsubsection{Caracterização da conformidade nos processos matrimoniais: conformidade formal ou substancial?}

Antes de se estudar a distinção entre a conformidade formal e a conformidade substancial, vale esclarecer que "o código exige apenas a dupla conformidade das decisões para a passagem em julgado ou quase julgado, e não a identidade das sentenças. A identidade acrescenta qualquer coisa à conformidade, e não se pode aplicar ao caso, pois as normas sobre o julgado devem ser interpretadas em sentido estrito, dado que comportam uma restrição dos direitos (o direito de apelação). A não identidade opera sobretudo no âmbito das motivações e do iter cognoscitivo dos fatos, que poderiam ser diversos em cada uma das decisões, mesmo chegando a um idêntico dispositivo" 161

\footnotetext{
159 ZUBILLAGA, José Luis López. La conformidad de decisiones en el Código de 1983. cit., p. 698.

160 Id. Ibid., p. 699-700.

161 CONDE, Manuel Jesus Arroba. Direito processual canônico. cit., p. 675. No mesmo sentido é a lição de José Francisco COLOMER: "La doctrina suele describir el concepto de la conformidad como una situación a caballo entre la 'identidad' (que no es necesaria) y la 'deformidad' (que evidentemente no puede absolver ninguna de las funciones que el derecho asocia a las decisiones conformes). La identidad añade algo a la conformidad, por la cual dos sentencias podrían decirse conformes, aun no siendo idénticas. La no-identidad opera sobre todo en el ámbito de las motivaciones y del camino cognoscitivo de los hechos, que podrían ser diversos en cada una de las decisiones, aun tendiendo a un idéntico dispositivo" (COLOMER, José Francisco. La doble sentencia conforme: ¿conformidad equivalente o conformidad formal? cit., p. 31).
} 
Esclareça-se desde já também que "no sería tampoco admisible una conformidad parcial o gradual, ya que la conformidad o es total o no es" 162

Como visto acima, a dupla conformidade é bifronte. Por um lado, é uma das hipóteses de formação de coisa julgada, o que significa impedimento à propositura de recurso ordinário contra a segunda sentença conforme. Por outro lado, entretanto, é condição de executoriedade da sentença proferida em causas sobre estado das pessoas, incluindo aquelas de nulidade de matrimônio e separação dos cônjuges. ${ }^{163}$

A dupla conformidade, em qualquer um dos seus aspectos, está ligada ao seu fundamento último, que é a salvação das almas. Mas, além disso, por trás do instituto há uma questão de técnica jurídica: a de se identificar ou não a causa de pedir com o capítulo de nulidade nas causas matrimoniais.

É só no segundo aspecto, portanto, porque envolve as causas matrimoniais, que se cogita do debate entre defensores da conformidade formal e defensores da conformidade substancial.

O tratamento da conformidade sofreu pequena alteração no Código de Direito Canônico de 1983 se comparado ao anterior Código de 1917. Com efeito, "este nuevo Código introduce un avance respecto al Código de 1917, ya que aquél, en su canon 1902, no definía en qué podía consistir dicha conformdiad. Sin embargo, el actual indica que la conformidad entre dos decisiones sólo puede producirse cuando ambas decisiones se den entre los mismos litigantes, sobre la misma petición hecha por los mismos motivos, es decir cuando se trate de la misma acción. Y no podía ser de otra forma ya que el proceso es, en definitiva, un proceso sobre la acción" 164

Entretanto, a lacuna existente no Código de 1917 não foi totalmente suprida pelo esclarecimento que procurou dar à conformidade o Código vigente ao afirmar ser necessária a coincidência de três elementos: partes, ${ }^{165}$ petição e causa de demanda, na

162 ZUBILlagA, José Luis López. La doble decisión conforme en la doctrina procesal del código de 1917. cit., p. 160.

163 O Código anterior não era expresso, como o atual, a respeito da inclusão das causas de separação entre as causas sobre o estado das pessoas. Entretanto, a doutrina já defendia esse posicionamento. Nesse sentido, DELLA ROCCA, Fernando. Il privilegio delle cause matrimoniali in ordine alla cosa giudicata nel diritto canonico. cit., p. 34.

164 ZUBILLAGA, José Luis Lópes. La conformidad de decisiones en el Código de 1983. cit., p. 651.

165 A palavra parte, aqui, deve ser lida como "posição processual". Com efeito, "para que se dé esa conformidad que piede el canon $1641,1^{\circ}$ la posición procesal de ambas partes debe permanecer intacta en las dos instancias que han llevado a una misma decisión. Si esa posición procesal fuese alterada, por ejemplo en el caso de que el actor pase a ser demandado o viceversa, no cabría la conformidad, aunque materialmente hablando se tratase de los mismos litigantes, como pide el canon en cuestión" (ZUBILLAGA, José Luis López. La conformidad de decisiones en el Código de 1983. cit., p. 654). Ou seja, "no se debe considerar a los sujetos respecto a su identidad física sino jurídica, ya que la identidad de la acción exige que se trate , no de las mismas personas físicas sino iuridice consideratas" (Id., p. 654). 
terminologia do Código. A expressão "causa de demanda" é, inclusive, ignorada pela doutrina, que se refere à necessidade de identidade de causa de pedir.

E a lacuna permanece justamente nesse ponto, uma vez que o Código não esclarece exatamente a que se refere a "causa de demanda" que, ainda que seja tomada como expressão sinônima de "causa de pedir", não é auto-explicativa. ${ }^{16}$

É justamente na divergência sobre o conteúdo da causa de pedir que reside o núcleo do embate doutrinário entre os partidários da conformidade formal e os partidários da conformidade substancial.

José Francisco Colomer desenvolveu brilhante estudo sobre o tema em sua tese de doutorado. ${ }^{167}$ Mister iniciar pela clara e precisa distinção entre as duas expressões: "la doctrina y la jurisprudência hablan de conformidad formal, cuando la nulidad del matrimonio se declara por el mismo capítulo de nulidad (identificándose así caput nullitatis con causa petendi); y de conformidad substancial o equivalente, cuando el acuerdo estriba en el reconocimiento de los mismos hechos jurídicos aunque se acepte la nulidad por diferentes capítulos (o sea, la diversidad de capítulos no implica un cambio de la causa petendi o título jurídico)" 168

Entre os autores partidários da conformidade formal, aponta: Luis Madero e J. Llobell. Acrescente-se a esse rol o espanhol José Luis López Zubillaga. ${ }^{169}$ Por outro lado, seriam adeptos da conformidade substancial, além de ele próprio: J. M. Serrano Ruiz, P. Moneta, A. Mcgrath, S. Villeggiante e N. Schöch.

Confira-se o posicionamento de cada um dos canonistas supramencionados, iniciando pelos partidários da conformidade formal.

De acordo com José Francisco Colomer, Luis Madero acredita que a conformidade substancial implicaria mudança arbitrária da fórmula de dúvida em segunda instância, ao arrepio da iniciativa das partes. ${ }^{170}$

Ocorre que, quer em primeira, quer em segunda instância, cabe à parte narrar os fatos que a seu ver ensejam o pedido de nulidade matrimonial. A determinação do capítulo de nulidade - e há disposição expressa do Código nesse sentido - é tarefa do juiz (v. item 5.4.2.1 infra).

\footnotetext{
166 José Francisco Castelló Colomer, no mesmo sentido, afirma que o Código "no deja claro, en particular qué se entiende por eadem causa petendi por lo que en princípio el CIC 83 no excluiria la conformidad equivalente" (COLOMER, José Francisco Castelló. La doble sentencia conforme... cit., p. 30).

167 Infelizmente, o acesso à bibliografia canônica não é fácil no Brasil e está disponível na biblioteca da Pontifícia Universidade Católica de Teologia apenas um excerto da mencionada tese de doutorado.

168 COLOMER, José Francisco Castelló. La doble sentencia conforme: ¿conformidad equivalente o conformidad formal?, p. 11-12.

169 Veremos adiante que apesar de partidário da conformidade formal, apresenta posicionamento flexível quando trata dos possíveis fundamentos pelos quais se pede anulação de matrimônio.

170 Id. Ibid., p. 32.
} 
J. Llobell, por sua vez, nega a existência de lacuna legal no tratamento da matéria $^{171}$ e afirma que a motivação da sentença não pode ser utilizada para justificar a conformidade substancial não desejada pelo legislador. ${ }^{172}$

Se a motivação é rejeitada sob o pretexto de que ao se exigir conformidade do dispositivo e da motivação estar-se-ia exigindo verdadeira identidade, ${ }^{173}$ parece não haver motivo de se negar com tanta veemência a utilização da motivação para justificar a conformidade substancial.

A motivação da sentença, ademais, é de grande importância no que diz respeito à coisa julgada. Com efeito, "la pars motiva della sentenza concorre alla migliore ed esatta determinazione dell'ambito di efficacia del giudicato, posto che non di rado la scarna parte dispositiva non è in grado di chiarificare quanto e come la sentenza possa incidere sulla realtà sostanziale e ad essa dare forma, rendendo doveroso un determinato dipositivo, e venendo così a costituire una tutela avverso comandi arbitrari" ${ }^{174}$

José Luis López Zubillaga, por fim, é incisivo ao negar a conformidade substancial. Afirma o autor que "esta corriente a favor de la conformidad equivalente o substancial de las decisiones no parece demasiado acorde con la normativa específica del canon $1641,1^{\circ}$, que parece exigir una verdadera conformidad formal, es decir sólo podrán considerarse conformes aquellas decisiones que, concordando en el rechazo o aceptación del objeto litigioso lo hagan en base a la misma causa petendi, porque ésta es condición necesaria y fundamento jurídico de lo pedido en la acción" 175

De outro lado, tem-se os favoráveis à conformidade substancial, criação da jurisprudência ainda na vigência do Código de $1917 .{ }^{176}$

\footnotetext{
Id. Ibid., p. 37.

Id. Ibid., p. 37.

173 Nesse sentido, José Luis López Zubillaga: "la conformidad afecta sólo a la parte dispositiva, ya que si las motivaciones y el iter cognoscitivo de los hechos es exactamente igual cabría hablar más que de conformidad de identidad. No obstante, los motivos fundados en los mismos hechos debieran ser esencialmente los mismos" (ZUBILLAGA, José Luis López. La conformidad de decisiones en el Código de 1983. cit., p. 655). Entretanto, o autor pondera que "es difícil pensar que dos decisiones referidas a la misma acción, es decir a los mismos sujetos, petitum y causa petendi próxima y remota, vayan a tener una motivación absolutamente diferente, en esse caso si realmente se da alguna vez, cabría hablar de conformidad aparente, especialmente si los hechos admitidos por una decisión son negados por la otra, ya que si los motivos son totalmente diferentes será porque, de alguna forma, se basan en hechos completamente distintos, y en ese caso la causa petendi próxima ya no sería la misma, tratándose, por tanto, de una acción diferente que no justificaría suficientemente la conformidad" (Id., p. 656).

174 BETTETINI, Andrea. Verità, giustizia, certezza... cit., p. 18-19.

175 ZUBILLAGA, José Luis López. La conformidad de decisiones en el Código de 1983. cit., p. 653

176 Isso nos faz pensar que o Código de 1983, ao explicitar o que se entendia por conformidade teve uma tentativa mal sucedida de adotar expressamente a conformidade substancial. Não haveria motivo para se ter uma reforma legislativa contrária à jurisprudência e a favor do retrocesso. Até porque "En las lagunas de ley, donde la jurisprudencia rotal es constante, esta se convierte en vinculante para todos los tribunales del mondo de conformidad con lo establecido en el c. 19" (COLOMER, José Francisco Castelló. La doble sentencia conforme... cit., p. 79).
} 
José Francisco Castelló Colomer analisa a obra de Mcgrath, reveladora do verdadeiro dilema em que por vezes se encontra o tribunal de segunda (ou terceira) instância: "el tribunal de segunda instancia, afirma McGrath, considerando la nulidad del matrimonio declarada en primera instancia, se encuentra a veces en un dilema. Los jueces, después de haber estudiado las actas y la sentencia de primera instancia, se pueden encontrar, tras una madura deliberación y reflexión, de acuerdo con la primera instancia sobre la cuestión básica de la nulidad, pero en desacuerdo sobre el capítulo de nulidad por el cual ha sido probado. En este caso, ¿qué puede hacer el tribunal de segunda instancia?" 177

Da análise da obra de J. M. Serrano Ruiz, extrai José Francisco Castelló Colomer que "la determinación del capítulo de nulidad de matrimonio en la disciplina canónica vigente es más bien un problema de expresión terminológica que de relevancia dogmática" 178

Afirma ainda que J. M. Serrano Ruiz utiliza-se, para justificar seu posicionamento favorável à conformidade substancial, de dois princípios informadores de todo o sistema: (i) menor peso das formalidades estritas na lei processual vigente e (ii) maior intervenção e atribuições que se reconhecem à legítima direção do juiz em relação ao processo. ${ }^{179}$

Por fim, analisando a obra de Paolo Moneta, também defensor da conformidade substancial, afirma José Francisco Castelló Colomer que "las indicaciones de la jurisprudencia rotal son, al menos predominantemente, en el sentido de dejar al juez un cierto margen de libertad en la calificación jurídica del hecho aducido como motivo de nulidad de las partes si actor seu actriz id non praestiterit aut verum non tribuerit, llegando así a dar una calificación jurídica de los hechos, bajo algunos aspectos, diversa de la enunciada en la formulación de la duda" 180

Paolo Moneta defende que a causa de pedir é constituída por uma área de nulidade e não por um único capítulo de nulidade. Esse argumento não só milita em favor da admissão da conformidade substancial como, ainda, impede a proposição de uma nova causa por capítulo diverso da causa anterior quando tais capítulos podem originar uma dupla conformidade. Nesse sentido, como afirma José Francisco Castelló Colomer, “aquel que ha obtenido una sentencia negativa por el capítulo del error qualitatis del c. 1097.2 no podría pues volver a proponer em primera instancia la causa por el error in persona del c. 1097.1, sino que debería dirigirse al tribunal de apelación" 181

177 COLOMER, José Francisco Castelló. La doble sentencia conforme: ¿conformidad equivalente o conformidad formal? Roma: Pontifica Università Lateranense, 2003. Excerptum theseos ad Doctoratum in Iure Canonico. p. 50 .

178 Id. Ibid., p. 39.

179 Id. Ibid., p. 42-43.

180 Id. Ibid., p. 49.

181 Id. Ibid., p. 50. 
Parecem estar com a razão referidos autores defensores da conformidade substancial.

Vale mencionar, ainda, a jurisprudência rotal.

José Francisco Castelló Colomer ${ }^{182}$ cita diversas decisões da Rota Romana que admitiram a conformidade substancial, tais como: (i) Coram Lanversin, 18.2.1984, na qual restou decidido que devem ser considerados os fatos narrados e provados pelas partes, não o nome jurídico que as partes lhes dêem; (ii) Coram Serrano, 24.10.1986, que também deu preferência aos fatos em relação à qualificação jurí́dica destes; (iii) Coram Stankiewicz, 26.2.1987, na qual se considera que foram atribuídas qualificações jurídicas diversas ao mesmo fato; (iv) CORAM PALESTRO, 21.12.1988, na qual restou decidido que a conformidade equivalente só está justificada pela ratio spiritualis e pela natureza pública das causas sobre o estado das pessoas que têm como objeto o bem público; (v) CORAM BRUNO, 24.2.1989; (vi) CORAM SERRANO, 1.6.1990; (vii) CORAM COLAGIOVANNI, 7.4.1992; (viii) CORAM BRUNO, 30.4.1993 e (ix) CORAM POMPEDDA, 22.10.1996, que reconheceu conformidade por causas atribuídas ora a uma parte ora à outra.

Em contrapartida, cita também uma decisão favorável à conformidade formal: CORAM STANKIEWICZ, 22.3.1994 que decidiu, segundo afirma José Francisco Castelló Colomer, que "se tiene conformidad formal, que es la pedida por la ley, cuando una causa se decide dos vezes, afirmativa o negativamente, por el mismo capítulo de nulidad" 183

É comum criticar-se a conformidade substancial sob o argumento de que “la razón de la introducción de está llamada ‘conformidad equivalente’ está inspirada en criterios de pastoralidad en virtud de los cuales, por economia procesal y por una cierta benignidad a la hora de tratar este tipo de causas, manifestada en lo que se há venido a llamar favor veritatis, se sacrifica la instrumentalidad procesal olvidando que es la base para poder llegar a la justicia fundada en la verdad" 184

182 COLOMER, José Francisco Castelló. La doble sentencia conforme: ¿conformidad equivalente o conformidad formal? Roma: Pontifica Università Lateranense, 2003. Excerptum theseos ad Doctoratum in Iure Canonico. p. 57-69.

183 Id. Ibid., p. 71.

184 ZUBILLAGA, José Luis López. La conformidad de decisiones en el Código de 1983. cit., p. 674. A crítica feita pelo mencionado autor não escapa dos cuidadosos olhos de José Francisco Castelló Colomer: "Suele acusarse e los que defienden la conformidad sustancial de ampararse em argumentos más bien pastorales y de equidad, pero hasta el momento no podemos decir que la mayor parte de los argumentos que se sostienen para defender exclusivamente la conformidad formal sean, en su acepción más genuína, jurídicos sino que se trata más bien de hipótesis que se elaboran, en gran parte, para descalificar la conformidad sustancial, sin prestar atención a los razonamientos netamente jurídicos que la fundamentan" (COLOMER, José Francisco Castelló. La doble sentencia conforme... cit., p. 55). 
Manuel Jesus Arroba Conde, entretanto, é categórico ao afirmar que não acredita "que sejam apenas razões pastorais para avaliar a legitimidade da conformidade equivalente. As razões são de índole estritamente jurídica, fundadas isto é na diferença que intercorre entre 'capítulos de nulidade' e 'causa petendi'. As normas substanciais sobre o direito matrimonial estão "abertas" com perfis indeterminados. Os mesmos fatos jurídicos são susceptíveis de fórmulas jurídicas diversas, sem que isto comporte diversidade da 'causa petendi' Ora bem, o poder do juiz de dar o 'nomem iuris' à controvérsia exerce-se na concordância da dúvida e não na própria sentença" 185

O conceito de causa de pedir é realmente mais amplo do que o de capítulo de nulidade. De acordo com José Francisco Colomer, "si el c. 1639.1 usa la expresión causa petendi y en el c. 1683 la de caput nullitatis es porque con ello quiere significar dos cosas, que aunque conexas, son distintas" 186

Podemos entender aqui a expressão "capítulo de nulidade" como o nomen iuris que se atribui ao fato descrito no libelo. A causa de pedir, por sua vez, "se constituye por los elementos de hecho y por el elemento jurídico. Por tanto, siempre que haya identidad de los hechos que sostienen la acción, no es necesario exigir la identidad del nomen iuris, por los que dos decisiones pueden ser conformes, fundadas sobre la misma causa petendi, aun no siendo identico el nomen iuris atribuído a los hechos que fundan la decisión" 187

Outra crítica normalmente feita à conformidade substancial é a de sua aceitação prejudicar o direito de defesa. No entanto, parece muito mais recomendável, em nome da instrumentalidade do processo, também presente, certamente, no direito canônico, aceitar a conformidade substancial e dar oportunidade de manifestação às partes, embora, como regra, as partes se defendam dos fatos e não da sua qualificação jurídica, do que simplesmente recusar a conformidade substancial e fechar os olhos para a realidade. ${ }^{188}$ Assim, surpresas serão evitadas, mas também se evitará atividade processual inútil em nome de um formalismo excessivo.

185 CONDE, Manuel Jesus Arroba. Direito processual canônico. cit., p. 676-677.

186 COLOMER, José Francisco Castelló. La doble sentencia conforme: ¿conformidad equivalente o conformidad formal? Roma: Pontifica Università Lateranense, 2003. Excerptum theseos ad Doctoratum in Iure Canonico. p. 26. A tradução brasileira do Código utiliza as expressões "título de demanda" (cânone $1639, \S 1^{\circ}$ ) e "fundamento de nulidade" (cânone 1683). Além disso, como já vimos, o cânone 1641 traz ainda outra expressão, qual seja, "causa de demanda", que parece-nos mais similar ao conceito de "titulo de demanda" do que ao de "fundamento de nulidade" Poderíamos identificar sem maiores problemas as expressões "título de demanda" e "causa de demanda" com "causa de pedir" e a expressão "fundamento de nulidade" com "capítulo de nulidade"

187 COLOMER, José Francisco Castelló. La doble sentencia conforme... cit., p. 27-28.

188 Nesse sentido, José Francisco Castello Colomer afirma que "el haber admitido un nuevo motivo de nulidad lleva consigo la necesidad de someterlo al contradictorio judicial desde su mismo planteamiento, aunque este tenga lugar ya bien avanzado el juicio y como consecuencia de lo que ha resultado de él. De otro modo cabría poner en duda las posibilidades de ejercicio del derecho de defensa, que es sagrado tanto para las 
Seria mais adequado, talvez, denominar tal conformidade formal de conformidade formalista (e entenda-se aqui o formalismo prejudicial e não aquele valorativo tão bem defendido por Carlos Alberto Alvaro de Oliveira ${ }^{189}$ ). Ao menos é isso o que vem à mente quando se lê que "la conformidad equivalente o substancial no sería verdadera conformidad, al menos por lo que se refiere al canon $1641,1^{\circ}$, puesto que faltaria la identidad en el nomen iuris de esos hechos que, siendo identicos para ambas decisiones, no concuerdan en la identificación del capítulo de nulidad" ${ }^{190}$

A simples distinção do nomen iuris não pode, com a devida vênia, ser considerada suficiente para se dizer que duas sentenças são diferentes quando elas são, ao contrário, substancialmente iguais!

É de se ter em mente, ainda, que "en cualquier contexto normativo se puede sostener, aún en la disciplina anterior, que cuando una parte solicita por un determinado motivo la nulidad, in directo et principaliter solicita la nulidad misma y sólo accesoriamente y como camino hacia ella señala el capítulo que estima más adecuado por la idea que tiene del caso y las pruebas de que dispone. Por tanto, no se ve tan claro que el juez vaya sustancialmente más allá de lo que pide la parte si ésta solicita la nulidad y el juzgador se la concede, en fuerza de lo alegado y probado en contradictorio, por distinto motivo del formalmente acusado" 191

\subsubsection{Causa de pedir nos processos matrimoniais}

Esclareça-se que o objetivo deste trabalho não é o de fazer um estudo comparado entre o processo canônico e o processo laico, motivo pelo qual, é imperioso esclarecer, a atenção voltar-se-á bibliografia de direito canônico.

Não será feito aqui um estudo teórico sobre a causa de pedir na teoria geral do processo. Para o presente estudo, basta ter presente que a causa de pedir se constitui dos elementos de fato e dos elementos jurídicos que embasam o pedido.

A causa de pedir nos processos matrimoniais guarda peculiaridades em relação à causa de pedir nos demais processos, pois muitas vezes um mesmo fato pode

partes como para el ministerio público del defensor del vínculo" (Id. Ibid., p. 44).

189 Cf. OLIVEIRA, Carlos Alberto Alvaro de. Do formalismo no processo civil: proposta de um formalismovalorativo. 3. ed. São Paulo: Saraiva, 2009.

190 ZUBILlaGA, José Luis López. La conformidad de decisiones en el Código de 1983. cit., p. 675. Vale ressaltar que "uma vez que o direito divino fundamenta o humano e é ordenado acima deste, o direito da Igreja é, por sua natureza, incompativel com toda concepção formalista e positivista que atribui às prescrições legais um valor absoluto e exclusivo" (FELICIANI, Giorgio Feliciani. As bases do direito da Igreja. Comentário ao Código de Direito Canônico. Trad. Pe. Tarcísio Machado Rocha. São Paulo: Paulinas, 1994. p. 81-82).

191 COLOMER, José Francisco Castelló. La doble sentencia conforme... cit., p. 44-45. 
dizer respeito a mais de um capítulo de nulidade e às vezes, ainda, um capítulo de nulidade contém ou está contido em outro.

É preciso ter em mente que "todo el ordenamiento matrimonial canónico está inspirado en el 'principio' de que la voluntad negocial de ambos contrayentes es la 'causa' (no mera condición 'sine qua non') 'única' (no mera causa) 'no sustituible' (vgr. por el ordenamiento jurídico) de la existencia (no de la esencia) de cada matrimonio concreto" 192

Nikolaus Schöch afirma que "la más antigua combinación para la declaración de la conformidad equivalente es la de miedo (can. 1103) y de simulación (can. 1101). La primer sentencia rotal que declaró la conformidad equivalente en este caso es anterior al CIC-1917, es decir, data de la época inmediatamente posterior a la reforma de la Curia Romana realizada por el Papa Pio X em $1908^{\prime 193}$ e aponta como possíveis combinações de capítulos de nulidade para a declaração da conformidade equivalente de duas sentenças as seguintes: (i) simulação e medo; (ii) simulação total e simulação parcial (apontando ser princípio geral que a segunda está incluída na primeira); (iii) simulação e capítulos de nulidade por incapacidade psíquica; (iv) medo e incapacidade psíquica; (v) condição, erro e dolo; (vi) simulação e condição; (vii) simulação e erro; (viii) falta de discrição de juízo e incapacidade para assumir as obrigações essenciais e (ix) incapacidade psíquica e erro ou dolo. ${ }^{194}$

A peculiaridade da causa de pedir nos processos matrimoniais é de tal monta que mesmo José Luis López Zubillaga, adepto da conformidade formal, tratando dos capítulos de nulidade, afirma que "en algunos de ellos existe una relación tan íntima que aun cuando no se trate, estrictamente hablando, del mismo capítulo de nulidad podría admitirse uma conformidad incluso formal entre ellos" 195

192 FAÍlLDE, Juan José Garcia. Princípios inspiradores del proceso de nulidad matrimonial. cit., p. 145.

193 SCHÖCH, Nikolaus. Criterios para la declaración de la conformidad equivalente de dos sentencias según la reciente jurisprudencia rotal. Anuario Argentino de Derecho Canónico, Santa Maria de los Buenos Aires, v. 11,2004 , p. 286.

194 Id. Ibid., p. 286-310.

195 ZUBILLAGA, José Luis López. La conformidad de decisiones en el Código de 1983. cit., p. 676. É interessante detalhar seu posicionamento: "En efecto, siempre que se trate de los capitulos del canon 1095 , supuesto que la concesión de cualquiera de ellos se base en las mismas pruebas en ambas instancias y se refieran al mismo sujeto, se daria una doble sentencia conforme, ya que, como hemos dicho, estos capítulos se relacionan de tal forma que el primero contiene a los otros dos y el segundo contiene al tercero" (Id., p. 677). Ainda, "lo mismo cabe decir de los dos tipos de erros recogidos en el canon 1097: el error em la persona (can. 1097, §1) y el error en cualidad de la persona (can. 1907, §2)" (Id., p. 677). Por fim, "1levando las cosas al extremo quizá también podría hablarse de conformidad entre dos sentencias que concediesen la nulidad del mismo matrimonio, una por error doloso del canon 1098 y otra por error redundante en la persona del canon $1907, \S 1$, supuesto que ambas decisiones estuviesen sustentadas en las mismas pruebas en las que quedase demostrado que existió simultáneamente un deseo de engañar a la otra parte por uno de los cónyufes acerca de las cualidades de su persona, y simultáneamente el error en la parte engañada acerca de la personalidad y sus cualidades del cónyuge que engaña" (Id., p. 678). Justificar-se-ia também a dupla conformidade nos casos em que houvesse uma sentença por simulação parcial e outra por simulação total, mas isso não se dá se duas sentenças forem proferidas por simulação parcial, mas por dois capitulos 
Por fim, admite-se, nas causas matrimoniais, apresentação de novo fundamento de nulidade em grau de apelação (cânone 1683). Nesses casos, se em grau de apelação for admitido esse novo fundamento, o julgamento dar-se-á como se fosse dado na primeira instância e assim será necessário novo recurso para obtenção da dupla conformidade.

\subsubsection{A importância da litis contestatio}

A litis contestatio, ao lado do libelo introdutório, da citação e do oferecimento de contestação, compõe a primeira fase do procedimento, chamada fase de preparação e “consiste nella fissazione inanzi al giudice dell'oggetto della controversia, che avviene mercè la 'concordanza del dubbio' sul quale dovrà intervenire la decisione" 196

Há quem prefira dar o nome de litiscontestação à toda fase de preparação afirmando que "este hecho [litiscontestación] reviste dos momentos: uno consistente en la iniciativa de las partes, primero mediante la petición del actor y luego con la contradicción del demandado; el segundo momento viene establecido por el acto del juez en el que determina la fórmula de dudas. En este último acto el juez fija la materia decidendi que incluye no sólo el petitum sino también la causa petendi" 197

O que importa realmente de tudo isso é que é o juiz que dá o nomen iuris aos fatos alegados pela parte. ${ }^{198}$

Embora o cânone 1504 afirme, no $\S 2^{\circ}$, que o libelo introdutório deve "indicar o direito em que se fundamenta o autor e, ao menos de modo geral, os fatos e provas que possam demonstrar o que é alegado" o cânone 1513 afirma que "dá-se a litiscontestação quando, por decreto do juiz, são definidos os termos da contorvérsia, deduzidos das petições e respostas das partes" (sem destaque no original). Assim, a indicação do direito feita pela parte não vincula o juiz.

Vale ressaltar que "la presenza del giudice è determinata invece non soltanto da esigenze processuali ed ha un valore che non è semplicemente strumentale per il compimento della litis contestatio" 199

Além disso, tem-se que as causas matrimoniais devem ser regidas pelas normas especiais contidas nos cânones 1671 a 1706 . E os $\S \S 2^{\circ}$ e $3^{\circ}$ do cânone 1677 são

diferentes (Id., p. 679). Vale ressaltar que nos casos apontados por José Luis López Zubillaga, não acredita ele haver conformidade substancial, pois existe uma mesma causa petendi já que a relação entre os capítulos é tão íntima que de alguma forma eles se contêm uns nos outros (Id., p. 680).

196 DEL GIUDICE, Vincenzo. Sommario di diritto canonico. cit., p. 141.

197 ZUBILLAGA, José Luis López. La conformidad de decisiones en el Código de 1983. cit., p. 657.

198 Id. Ibid., p. 657.

199 MAZZACANE, Elio. La litis contestatio nel processo civile canonico. Napoli: Jovene, 1954, p. 67. Embora o livro tenha sido escrito sob a vigência do Código de 1917, a afirmação ainda é perfeitamente válida atualmente. 
expressos no sentido de que o juiz é quem determina a fórmula da dúvida ou dúvidas, na qual também o juiz deve determinar por qual título ou quais títulos é impugnada a validade das núpcias.

Essa atividade de determinação da fórmula da dúvida ou dúvidas deve ser exercida com muita cautela, pois o decreto de litiscontestação condiciona o conteúdo da sentença e é pelo conteúdo da sentença que será possível aferir se há ou não dupla conformidade.

Assim, "se a qualificação jurídica do fato que gera a nulidade depende apenas das preferências subjetivas do juiz, quando existe uma legítima variedade de opiniões doutrinárias, o tribunal de apelação deve limitar ao máximo a incidência de suas preferências, mesmo porque a norma aplicada em primeiro grau seja igualmente legítima e idônea para integrar os fatos históricos e as provas coletadas" ${ }^{200} \mathrm{E}$ isso se aplica mesmo à Rota Romana de modo que "se houver identidade sobre o fato generativo da nulidade, averiguado em primeira instância e na instância rotal, a diferente qualificação jurídica do mesmo na segunda decisão não deve impedir a execução imediata" ${ }^{201}$

\subsubsection{Ainda os processos matrimoniais: a instrução Dignitas Connubii}

Em 25 de janeiro de 2005 foi apresentada ao público a instrução Dignitas Connubii (aprovada pelo Papa João Paulo II em 8 de novembro de 2004), a qual trouxe algumas novidades no âmbito do processo canônico de nulidade matrimonial.

Tal instrução é importante para o objeto do presente estudo uma vez que, superando a discussão acima abordada sobre se deve ser considerada a conformidade formal ou a conformidade substancial das sentenças, afirma, em seu artigo $291, \S 2^{\circ}$ inspirado na jurisprudência da Rota Romana, que "consideram-se equivalentes ou substancialmente conformes as decisões que, embora indiquem e determinem com um nome diferente 0 capítulo de nulidade, no entanto se fundamentam nos mesmos fatos que causam a nulidade do matrimônio e nas mesmas provas"

Interessante observar a exigência de que, além de se basearem nos mesmos fatos, tenham as sentenças que se basear nas mesmas provas. Entretanto, "tale riferimento non può essere inteso in senso rigoroso, tale da escludere la conformità ogni qualvolta il secondo giudice abbia basato il proprio convincimento su alcuni mezzi di prova che non erano stati utilizzati nella precedente istanza. Siffatta evenienza si verifica abitualmente, perché nella maggior parte dei casi il secondo giudice perviene ad una diversa qualificazione giuridica proprio in virtù di ulteriori e più convincenti elementi di prova che riesce a reperire

\footnotetext{
200 CONDE, Manuel Jesus Arroba. Direito processual canônico. cit., p. 677.

201 Id. Ibid., p. 677.
} 
a favore di essa. Se si negasse in tal caso la conformità delle sentenze si verrebbe in pratica a svuotare la regola della conformità sostanziale, arrivando ad esiti del tutto contrari alla giurisprudenza in materia e, consequentemente, ache alla norma che ad essa fedelmente si riporta", 202

Manuel Jesus Arroba Conde, analisando a Dignitas Connubii, afirma que "ao dar plena legitimidade à conformidade equivalente, a instrução precisa que esta se realiza entre dois capítulos de nulidade diversos que se fundamentam não apenas sobre os mesmos fatos mas também sobre as mesmas provas $(291,2)$. Insiste-se igualmente na importância de determinar a dúvida na 'litis contestatio' e requer-se que haja causa grave para prover a sua mudança, (136), pela qual o recurso (ora reconhecido) à conformidade equivalente não deixa espaço a inúteis e gratuitas mudanças do 'nomen iuris' que comprometam o direito de defesa; compete ao tribunal que emitiu a segunda decisão, ou ao tribunal superior, estabelecer existência da conformidade $(291,3)$ " 203

Vale mencionar ainda o texto do artigo $116, \S 1,2^{\circ}$. que exige das partes a apresentação das razões do pedido, mas exime-as de utilizar termos técnicos, ou seja, o nomen iuris, o que corrobora tudo o que foi dito no item anterior. ${ }^{204}$

Em relação à fórmula da dúvida (artigos 135 a 137), a instrução em nada se diferenciou do que já previa o Código. Apenas para complementar essa idéia, temse que "va indubbiamente riconosciuto al giudice il potere di interpretare in termini giuridicamente più corretti le istanze avanzate da ciascuno dei due coniugi, specialmente se queste vengono presentate in forme non strettamente tecniche, come può avvenire quando la parte non si avvalga dell'opera di un avvocato, o comunque di un esperto di diritto. Questo potere di interpretazione va riconosciuto nella fase di determinazione della formula del dubbio, nell'ambito della quale il giudice può indubbiamente modificare il capo di nullità formalmente proposto dall'attore, in modo da renderlo più aderente alla vicenda umana da questi prospettata e, ove occorra, anche più in linea con l'impostazione giuridica più comunemente seguita dalla giurisprudenza". ${ }^{205}$

202 MONETA, Paolo. La determinazione della formula del dubbio e la conformità della sentenza nell'istr. 'Dignitas Connubii'. Ius Ecclesiae, Milano, v. 18, n. 2, magg./ag. 2006. p. 432-433.

203 CONDE, Manuel Jesus Arroba. Direito processual canônico. cit., p. 677-678.

204 Confira-se o texto integral de referido parágrafo:

"Art. 116 - §1. O libelo, pelo qual se introduz a causa, deve:

(...)

$2^{\circ}$ delimitar o objeto da causa, isto é, especificar o matrimônio do qual se trata, apresentar um pedido de declaração da nulidade e propor, mesmo sem usar termos técnicos, a razão do pedido, ou seja, o capítulo ou os capítulos de nulidade pelos quais se impugna o matrimônio;

$(\ldots)$ "

205 MONETA, Paolo. La determinazione della formula del dubbio e la conformità della sentenza nell 'istr... cit., p. 421. 
Por fim, tem-se que a instrução, apesar de tentar superar a divergência doutrinária no tocante à conformidade formal e à conformidade substancial nas causas matrimoniais, ainda provoca polêmicas. Paulo Moneta, por exemplo, acredita que as determinações da instrução podem levar a uma declaração de nulidade não desejada pelo autor além de trazer o risco de comprometer o direito de defesa da outra parte. ${ }^{206}$

Ressalte-se, por fim, que a polêmica referente à conformidade continua a existir em todas as demais causas submetidas à jurisdição canônica uma vez que a instrução Dignitas Connubii aplica-se apenas às causas matrimoniais.

\subsection{Código das Igrejas orientais}

Se é difícil o acesso à bibliografia referente ao Código das Igrejas latinas, o que se dizer então em relação ao Código das Igrejas orientais?

Parece suficiente, entretanto, para os limites e objetivos deste trabalho, ter-se em mente que, no Código das Igrejas orientais, "a lei canônica ocidental foi praticamente reproduzida no que se refere à sistemática recursal e ao regime da coisa julgada, exigindo também, o cânone $1.322,1^{\circ}$, do Código das Igrejas orientais, a 'dupla conforme" para a sentença alcançar o trânsito em julgado, ressalvadas as causas de statu personarum (c. $1.324) " 207$

No mesmo sentido, tem-se que "en general, el Código oriental repite esencialmente las mismas disposiciones del Código latino, con las excepciones própias de la estructura de las Iglesias orientales, como por ejempo la existencia de un tribunal estable de tercera instancia que es el tribunal del Patriarca, o tribunal ordinario de la Iglesia patriarcal. (...) A esta peculiar estructura jurisdiccional es de aplicación igualmente todo lo dicho hasta aqui acerca de la doble conformidad de decisiones" 208

Algum problema pode surgir em decorrência do fato de que a instrução Dignitas Connubii é expressa em seu artigo primeiro no sentido de que só se aplica aos tribunais da Igreja latina, de modo que não é possível afirmar, diante disso, como ficaria a situação das Igrejas orientais, embora seja razoável aceitar, como já dito nos itens precedentes, que a conformidade formal já poderia ser aplicada nas Igrejas orientais como, de resto, nas latinas - mesmo antes - ou na ausência - de tal instrução.

\footnotetext{
206 MONETA, Paolo. La determinazione della formula del dubbio e la conformità della sentenza nell'istr. 'Dignitas Connubii'. Ius Ecclesiae, Milano, v. 18, n. 2, magg./ag. 2006. p. 423.

207 TUCCI, José Rogério Cruz e; AZEVEDO, Luiz Carlos de. Lições de processo civil canônico. cit., p. 86.

208 ZUBILLAGA, José Luis López. La conformidad de decisiones en el Código de 1983. cit., p. 701.
} 


\subsection{Jurisdição Comum vs. Jurisdição Canônica}

Já foi exaustivamente tratado o tema da coisa julgada e da conseqüente possibilidade de se revisar a sentença transitada em julgado no ordenamento canônico.

Entretanto, ainda resta uma pergunta: como fica uma sentença proferida por um tribunal eclesiástico diante do ordenamento civil?

Fernando Della Rocca afirma, na vigência do Código de 1917, que "dada la naturaleza especial de la jurisdicción eclesiástica, cuya potestad, lo mismo que la de orden, está por derecho nativo reservada exclusivamente a los clérigos (c. 118), la doctrina canónica, siguiendo las huellas del jus decretalium, considera competente para resolver un conflicto de jurisdicción entre el fuero civil y el fuero eclesiástico al juez eclesiástico, quien en caso de duda mantedrá la preeminência de la jurisdicción de la Iglesia" 209

No entanto, parece não ser essa a lógica, devendo o ordenamento estatal, soberano que é, determinar as hipóteses e o modo em que acatará a sentença proferida por um tribunal eclesiástico quando a competência for concorrente. ${ }^{210}$

Nesse sentido, em relação às causas matrimoniais, o próprio Código de Direito Canônico vigente prevê que "as causas relativas aos efeitos meramente civis do matrimônio competem ao magistrado civil, a não ser que o direito particular estabeleça que elas, quando tratadas incidente e acessoriamente, podem ser conhecidas e decididas pelo juiz eclesiástico" (cânone 1672). A expressão direito particular, nesse contexto, deve ser entendida como o direito de cada país, tendo em vista que o Código Canônico vale para diversos países.

$\mathrm{Na}$ União Européia - e principalmente na Espanha - o assunto parece ser muito mais bem desenvolvido do que aqui.

\section{Conclusão}

O Direito Canônico teve o grande mérito de, ao longo da história, ofertar à comunidade jurídica o conceito de trânsito em julgado, assimilado já há muito tempo pelos processualistas laicos.

Outra particularidade do direito canônico que interessa ao processo civil é a de considerar a coisa julgada como um valor não absoluto e não intrínseco ao exercício da jurisdição e ao desenvolvimento do processo. Como valor que é, pode ser cotejado

209 DELLA ROCCA, Fernando. Instituciones de derecho procesal canónico. cit., p. 151.

210 Nas matérias de competência exclusiva dos tribunais eclesiásticos, seria até desnecessário dizer, não há qualquer margem para discussão. Algumas causas conexas podem ser de competência exclusiva da Igreja, mas "para que se possa falar de jurisdição exclusiva da Igreja sobre certas coisas anexas às espirituais, a união entre o temporal e o espiritual deve ser tal que formem um único instituto jurídico, sem possibilidade de separação" (HORTAL, Pe. Jesús. Código de direito canônico. cit., p. 344). 
com outros e flexibilizado. ${ }^{211} \mathrm{Tal}$ idéia tem sido utilizada pelos cultores da relativização da coisa julgada no processo civil.

Mas nem só pelas influências recíprocas entre processo canônico e processo laico é que apresenta interesse o estudo da coisa julgada no âmbito do processo canônico. Como visto, não só o direito canônico é justificadamente um ramo completamente autônomo, como é profícua a discussão doutrinária entre os canonistas.

Se há ou não há trânsito em julgado das decisões proferidas nas causas sobre o estado das pessoas, o aspecto bifronte da exigência da dupla conformidade, a discussão doutrinária entre os adeptos da conformidade formal e os adeptos da conformidade substancial e a superação da discussão trazida pela instrução Dignitas Connubii no âmbito das causas matrimoniais, a particularidade apresentada pela causa de pedir nos processos matrimoniais e a importância da litis contestatio no âmbito do processo canônico foram os principais temas que, dentro da dogmática canônica, foram abordados neste trabalho.

Nesse contexto, é de grande importância, pela riqueza de argumentos jurídicos apresentada pelos canonistas, o estudo sobre a coisa julgada no direito canônico. São muitas as nuances que apresenta o tema e espera-se que o trabalho desenvolvido esteja à altura de sua importância.

São Paulo, novembro de 2010

\section{Referências}

ALVARO DE OLIVEIRA, Carlos Alberto. Do formalismo no processo civil: proposta de um formalismo-valorativo. 3. ed. São Paulo: Saraiva, 2009.

AZEVEDO, Luiz Carlos de; TUCCI, José Rogério Cruz e. Lições de processo civil canônico (história e direito vigente). São Paulo: Editora Revista dos Tribunais, 2001.

MOREIRA, José Carlos Barbosa. Eficácia da sentença e autoridade da coisa julgada. In: Temas de direito processual. São Paulo: Saraiva, 1984. Terceira série, p. 99-113.

BETTETINI, Andrea. Verità, giustizia, certezza: sulla cosa giudicata nel diritto della chiesa. Padova: CEDAM, 2002.

CAPOGRASSI, Giuseppe. Giudizio processo scienza verità. Rivista di diritto processuale, Padova, v. 5, pt. 1, p. 1-22, 1950.

211 Como afirma Eduardo Talamini, "trata-se de compreender o caráter politico da coisa julgada: um elemento a ser empregado pela ordem jurídica na medida em que produza resultados adequados aos fins da jurisdição" (TALAMINI, Eduardo. Eficácia e autoridade da sentença canônica. cit., p. 61). 
COLOMER, José Francisco Castelló. La doble sentencia conforme: ¿conformidad equivalente o conformidad formal? Roma: Pontifica Università Lateranense, 2003. Excerptum theseos ad Doctoratum in Iure Canonico.

COMOLLI, Alberto. La costituzione del rapporto processuale canonico. Milano: Giuffrè, 1969.

CONDE, Manuel Jesus Arroba. Direito processual canônico. Trad. por Côn. Dr. Martin Segú Girona. 5. ed. Roma: Institutum Iuridicum Claretianum, 2006.

Verità e principio della doppia sentenza conforme. In: BONNET, Piero Antonio; GULLO, Carlo (a cura di). Verità e definitività della sentenza canonica. Città del Vaticano: Libreria Editrice Vaticana, 1997. p. 59-77.

CRESCENTI, José Geraldo Caiuby. Instrução e julgamento de processos: anotações de prática processual canônica. Rio de Janeiro: Lumen Juris, 2007.

DALLA VILLA, Cristina. Sulla revisione della sentenza ecclesiastica di nullità matrimoniale già delibata: rilevanza civile. In: BONNET, Piero Antonio; GULLO, Carlo (a cura di). Verità e definitività della sentenza canonica. Città del Vaticano: Libreria Editrice Vaticana, 1997. p. 131-152.

DANEELS, Frans. Una introducción general a la instrucción Dignitas Connubii. Ius Canonicum, Navarra, v. XLVI, n. 91, p. 33-58, enero/jun. 2006.

DEL GIUDICE, Vincenzo. Sommario di diritto canonico. Milano: Giuffrè, 1946.

DELLA ROCCA, Fernando. Appunti sui gravami nel processo canonico. In: . Saggi di diritto processuale canonico. Padova: CEDAM, 1961. p. 159-176.

. Il privilegio delle cause matrimoniali in ordine alla cosa giudicata nel diritto canonico. In: . Saggi di diritto processuale canonico. Padova: CEDAM, 1961. p. 1-40.

. Instituciones de derecho procesal canónico. Buenos Aires: Desclée de Brower, s/d.

. Processo canonico. In: AZARA, Antonio; EULA, Ernesto. Novissimo digesto italiano. Torino: Editrice Torinese, 1968. v. XIII, p. 1095-1099.

Regiudicata (diritto processuale canonico). In: AZARA, Antonio; EULA, Ernesto. Novissimo digesto italiano. Torino: Editrice Torinese, 1973. v. XV, p. 234-235.

Tribunali ecclesiastici. In: AZARA, Antonio; EULA, Ernesto. Novissimo digesto italiano. Torino: Editrice Torinese, 1986. v. XIX, p. 753-761.

DIEGO-LORA, Carmelo de. De la cosa juzgada y de la restitución 'in integrum' In: MARZOA, A.; MIRAS, J.; RODRÍGUEZ-OCAÑA, R. (Coord.). Comentário exegético al código de derecho canónico. 2. ed. Pamplona: EUNSA, s/d. v. IV/2, p. 1.673-1.738.

FAÍLDE, Mons. Juan José García. Nuevo derecho procesal canónico: estudo sistemático-analítico comparado. 3. ed. Salamanca: Publicaciones Universidad Pontifica, 1995. 
Princípios inspiradores del proceso de nulidad matrimonial. Ius Canonicum, Navarra, v. XXVII, n. 53, p. 145-157, enero/jun. 1987.

FARIS, John. La storia della codificazione orientale. In: BHARANIKLLANGARA, Kuriakose (a cura di). Il diritto canonico orientale nell'ordinamento ecclesiale. Città del Vaticano: Libreria Editrice Vaticana, 1995. p. 255-268.

FELICIANI, Giorgio. As bases do direito da Igreja. Comentário ao Código de Direito Canônico. Trad. Pe. Tarcísio Machado Rocha. São Paulo: Paulinas, 1994.

FERRAZ JR., Tércio Sampaio. Segurança jurídica, coisa julgada e justiça. Revista do Instituto de Hermenêutica Juridica, Porto Alegre, v. 1, n. 3, p. 263-278, 2005.

FÜRST, Carl Gerold. Interdipendenza del diritto canonico latino ed orientale. Alcune osservazioni circa il diritto canonico della Chiesa Cattolica. In: BHARANIKULANGARA, Kuriakose (a cura di). Il diritto canonico orientale nell'ordinamento ecclesiale. Città del Vaticano: Libreria Editrice Vaticana, 1995. p. 13-33.

GHIRLANDA, Gianfranco. Introdução ao direito eclesial. Trad. Roberto Leal Ferreira. São Paulo: Loyola, 1998.

GIRONA, Côn. Martin Segú. O código de direito canônico é necessário na Igreja de Cristo? Revista de Cultura Teológica, São Paulo, v. 15, n. 58, p. 107-126, jan./mar. 2007.

. A metodologia canônica e o processual. Revista de cultura teológica, São Paulo, v. 10, n. 41, p. 57-86, out./dez. 2002.

GROCHOLEWSKI, Zenon. La especificidad del derecho canónico. Anuario argentino de derecho canonico, Santa Maria de los Buenos Aires, v. XII, p. 217-232, 2005.

Princípios inspiradores del proceso canónico ordinario. Ius Canonicum, Navarra, v. XXXIX, n. 78, p. 463-501, jul./dic. 1999.

HERNÁNDEZ, Miguel Moreno. Derecho Procesal Canónico. Madrid: Aguilar, 1956.

HORTAL, Pe. Jesús. Código de direito canônico. 9. ed. São Paulo: Loyola, 2008.

LLANO CIFUENTES, Rafael. Curso de direito canônico: a Igreja e o Estado à luz do Vaticano II. São Paulo: Saraiva, 1971.

LIMA, Mons. Maurílio César de. Introdução à história do direito canônico. 2. ed. São Paulo: Loyola, 2004.

LOPES, José Reinaldo de Lima. O direito na história: lições introdutórias. 3. ed. São Paulo: Atlas, 2008.

LOURENÇO, Luiz Gonzaga. Direito canônico em perguntas e respostas. Santos: EDUL, 2002. 
MARIAROSA, Barbara. La fase introduttoria del processo: problematiche sulla presentazione, ammissione e reiezione del libello. Roma: Pontifica Università Lateranense, 2002. Excerptum theseos ad Doctoratum in Iure Canonico

MARZOA, A., MIRAS, J., RODRÍGUEZ-OCAÑA, R. (Coord.). Comentário exegético al código de derecho canónico. 2. ed. Pamplona: EUNSA, s/d. v. 4, t. 2.

MAZZACANE, Elio. Il giudicato canonico e la certezza del diritto. In: RACCOLTA di scritti in onore di Arturo Carlo Jemolo. Milano: Giufrrè, 1963. v. 1, t. 2, p. 879-894.

La litis contestatio nel processo civile canonico. Napoli: Jovene, 1954.

MONDIN, Paola Buselli. Il sistema dei ricorsi e dei decreti nel processo matrimoniale canonico: spunti di teoria generale dell'atto giuridico per una definizione del concetto di atto processuale canonico. Roma: Lateran University Press, 2004.

MONETA, Paolo. La determinazione della formula del dubbio e la conformità della sentenza nell'istr. 'Dignitas Connubii'. Ius Ecclesiae, Milano, v. 18, n. 2, p. 417-438, magg./ag. 2006.

MORAN, Sabino Alonso; CABREROS DE ANTA, Marcelino. Comentarios al codigo de derecho canónico. Madrid: Editorial catolica, s/d. v. III

MUSSELLI, Luciano. Il concetto di giudicato nelle fonti storiche del diritto canonico (dalle origini al XVII ${ }^{\circ}$ secolo). Padova: CEDAM, 1972.

PELLEGRINO, Piero. La salus animarum. Ius Canonicum, Navarra, v. 64, n. 87, p. 141-151, enero/ jun. 2004.

PINTO, Junior Alexandre Moreira. Conteúdo e efeitos das decisões judiciais. São Paulo: Atlas, 2008 .

SALA, F. Vega. La eficacia civil de las sentencias canônicas. Nueva tendencia en los concordatos. El ejemplo español. Revista española de derecho canónico, Salamanca, v. 48, n. 130, p. 129-150, enero/jun. 1991.

SALERNO, Francesco. La doppia sentenza conforme nel processo matrimoniale canonico: ipotetici precedenti medievali. In: BONNET, Piero Antonio; GULLO, Carlo (a cura di). Verità e definitività della sentenza canonica. Città del Vaticano: Libreria Editrice Vaticana, 1997. p. 7-18.

SALVADOR, Carlos Corral (Dir.); EMBIL, José Maria Urteaga. Dicionário de direito canônico. São Paulo: Loyola, 1993.

SAMPEL, Edson Luis. Direito processual canônico. Revista de Cultura Teológica, São Paulo, v. 11, n. 43, p. 133-142, abr/jun. 2003.

. Introdução ao direito canônico. São Paulo: LTr, 2001.

SOARES, Carlos Henrique. Coisa julgada constitucional: teoria tridimensional da coisa julgada: justiça, segurança jurídica e verdade. Coimbra: Almedina, 2009. 
SCHÖCH, Nikolaus. Criterios para la declaración de la conformidad equivalente de dos sentencias según la reciente jurisprudencia rotal. Anuario Argentino de Derecho Canónico, Santa Maria de los Buenos Aires, v. 11, p. 267-378, 2004.

SURGIK, Aloísio. Compêndio de direito processual canônico. Curitiba: Livro é Cultura, 1988.

TALAMINI, Eduardo. Eficácia e autoridade da sentença canônica. Revista de Processo, São Paulo, v. 107 , p. 24-63, jul./ set. 2002.

. Coisa julgada e sua revisão. São Paulo: Revista dos Tribunais, 2005.

TOJO, Manuel Calvo. Reforma del proceso matrimonial anunciada por el papa. Salamanca: Publicaciones Universidad Pontifícia, 1999.

ZUBILLAGA, José L. López. La doble decisión conforme en la doctrina procesal del código de 1917. Revista Española de derecho canónico, Salamanca, v. 59, n. 152, p. 129-195, enero/jun. 2002. La conformidad de decisiones en el código de 1983. Revista Española de Derecho Canónico, Salamanca, v. 59, n. 153, p. 649-703, jul./dic. 2002. 